The role of polyols and amino acids in the maintenance of homeostasis in the skin

Ph.D. Thesis

Csilla Korponyai M.D.

Doctoral School of Clinical Medicine

University of Szeged

Supervisor:

Gábor Erős M.D., Ph.D.

Department of Dermatology and Allergology

University of Szeged

Szeged, Hungary

2016 
$\begin{array}{ll}\text { LIST OF PUBLICATIONS } & 4\end{array}$

1. LIST OF ABBREVIATIONS 6

2. INTRODUCTION 7

2.1. BACKGROUND 7

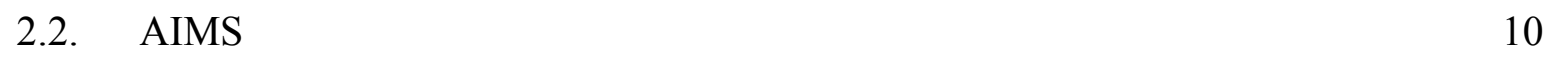

3. MATERIALS AND METHODS 11

3.1. MATERIALS 11

3.2. SUBJECTS AND ETHICAL CONSIDERATIONS 11

3.3. SKIN PHYSIOLOGICAL MEASUREMENTS 12

3.4. IN VITRO AND IN VIVO MICROBIOLOGICAL EXAMINATIONS 12

3.5. STUDY DESIGN 13

3.6. HISTOLOGY AND IMMUNOHISTOCHEMISTRY 16

3.7. STATISTICAL ANALYSIS 16

\begin{tabular}{ll} 
4. & RESULTS \\
\hline
\end{tabular}

$\begin{array}{lll}\text { 4.1. } & \text { STUDY I. } & 17\end{array}$

4.1.1. EFFECTS OF POLYOLS ON SKIN IRRITATION 17

4.1.2. EFFECTS OF AMINO ACIDS ON SKIN IRRITATION 19

4.2. STUDY II. $\quad 21$

4.2.1. IN VITRO AND IN VIVO ANTIBACTERIAL EFFECTS OF POLYOLS 21

4.2.2. EFFECTS OF POLYOLS ON SKIN PHYSIOLOGICAL PARAMETERS $\begin{array}{ll}\text { WITHIN } 24 \text { HOURS } & 23\end{array}$

$\begin{array}{lll}\text { 4.3. STUDY III. } & 23\end{array}$

4.3.1. EFFECTS OF POLYOLS ON SKIN PHYSIOLOGICAL PARAMETERS WITHIN 14 DAYS 
4.3.2. EFFECTS OF POLYOLS ON MORPHOLOGICAL PARAMETERS

$\begin{array}{lll}\text { 5. DISCUSSION } & 35\end{array}$

6. SUMMARY AND NEW FINDINGS 40

7. ACKNOWLEDGMENTS 41

8. REFERENCES 42 


\section{LIST OF PUBLICATIONS}

\section{LIST OF FULL PAPERS RELATED TO THE SUBJECT OF THE DISSERTATION}

I. Korponyai C, Kovács RK, Erős G, Dikstein S, Kemény L. Antiirritant properties of polyols and amino acids. Dermatitis 2011; 22: 141-146. (IF: 1.211)

II. Erős G, Korponyai C, Szabó K, Behány Z, Szél E, Kemény L. Antibacterial and skin hydrating effects of Xylinep ${ }^{\circledR}$ gel containing glycerol- and xylitol. Bőrgyógyászati és Venerológiai Szemle 2014; 90: 152-155. (Hungarian) (IF: 0)

III. Korponyai C, Szél E, Behány Z, Varga E, Mohos G, Dura A, Dikstein S, Kemény L, Erös G. The effects of locally applied glycerol and xylitol on the hydration, barrier function and morphological parameters of the skin. Acta DermatoVenereologica DOI: 10.2340/00015555-2493 (IF: 3.678)

\section{ABSTRACT RELATED TO THE SUBJECT OF THE DISSERTATION}

Korponyai C, Szél E, Behány Z, Mohos G, Dikstein S, Nagy K, Kemény L, Erős G. A lokálisan alkalmazott glicerol, xilitol és metionin hatásai a bőr hidratációjára, barrier funkciójára és morfológiájára. Bőrgyógyászati és Venerológiai Szemle 2014; 90(6): 275.

\section{LIST OF OTHER FULL PAPERS}

I. Szél E, Polyánka H, Szabó K, Hartmann P, Degovics D, Balázs B, Németh IB, Korponyai C, Csányi E, Kaszaki J, Dikstein S, Nagy K, Kemény L, Erős G. Anti-irritant and anti-inflammatory effects of glycerol and xylitol in sodium lauryl sulfate-induced acute irritation. Journal of the European Academy of Dermatology and Venereology 2015; 29(12):2333-2341. (IF: 3.029)

II. Meszes A, Korponyai C, Orvos H, Csoma Z. Transient zebra-like hyperpigmentation in a healthy newborn. The Indian Journal of Pediatrics 2016; 83(7):758-759. (IF: 0.808) 


\section{LIST OF OTHER ABSTRACTS}

1. Korponyai C, Altmayer A, Varga E, Szőke A, Bata-Csörgő Zs, Kemény L: Myeloma multiplex és amyloidosis együttes előfordulása. Bőrgyógyászati és Venerológiai Szemle 2009; 85:248.

2. Degovics D, Erős G, Hartmann P, Gáti K, Németh IB, Czóbel M, Korponyai C, Nagy K, Kemény L. The effects of oxygen- and hydroxyproline-containing solutions on the healing of acute wounds. Clinical Hemorheology and Microcirculation 2013; 54(2):193-194.

3. Szél E, Erős G, Hartmann P, Németh IB, Degovics D, Korponyai C, Dikstein S, Boros M, Nagy K, Kemény L. Anti-irritant and anti-inflammatory effects of polyols in irritant contact dermatitis. Clinical Hemorheology and Microcirculation 2013; 54(2):205.

4. Szél E, Erős G, Hartmann P, Degovics D, Korponyai C, Boros M, Dikstein S, Nagy K, Kemény L: Poliolok antiirritáns és gyulladáscsökkentő hatása irritatív kontakt dermatitiszben. Bőrgyógyászati és Venerológiai Szemle 2013; 89(6):179.

5. Szél E, Erős G, Hartmann P, Németh I, Degovics D, Korponyai C, Kaszaki J, Polyánka H, Szabó K, Dikstein S, Nagy K, Kemény L: Poliolok antiirritáns és gyulladáscsökkentő hatása irritatív kontakt dermatitiszben. Bőrgyógyászati és Venerológiai Szemle 2014; 90(6):261. 


\section{LIST OF ABBREVIATIONS}

$25 \mathrm{p}: 25^{\text {th }}$ percentile

$75 \mathrm{p}: 75^{\text {th }}$ percentile

ACD: Allergic contact dermatitis

AD: Atopic dermatitis

A.U.: Arbitrary unit

CFU: Colony forming unit

DAB: 3,3'-diaminobenzidine

DEJ: Dermal-epidermal junction

H\&E: Haematoxylin-eosin

HLA-DR: Human leukocyte antigen DR

ICD: Irritant contact dermatitis

m: Mean value

M: Median value

MMP-1: Matrix metalloproteinase-1

NMF: Natural moisturizing factor

PBS: Phosphate buffered saline

PPLO: Pleuropneumonia-like organism

ROS: Reactive oxygen species

S. aureus: Staphylococcus aureus

S. pyogenes: Streptococcus pyogenes

SC: Stratum corneum

SD: Standard deviation

SLS: Sodium lauryl sulfate

TauT: Taurine transporter

TEWL: Transepidermal water loss

TSA: Tryptic soy agar

TSB: Tryptic soy broth

UV: Ultraviolet 


\section{INTRODUCTION}

\subsection{BACKGROUND}

The most important function of the skin is to form a barrier which provides protection against environmental physical and chemical challenges so as against causative agents. In this barrier, physical and chemical/biochemical factors can be distinguished. Stratum corneum (SC) is the most significant part of the physical barrier, but the nucleated epidermis and its tight junctions also play a role. Concerning chemical/biochemical factors, antimicrobial peptides, enzymes, macrophages hamper the invasion of pathogens. Moreover, the barrier prevents the loss of water and solutes (Proksch et al., 2008). However, certain pathological conditions may interfere with this complex multifactorial barrier. Inter alia, different types of contact dermatitis (irritant contact dermatitis - ICD and allergic contact dermatitis - ACD) and atopic dermatitis (AD) are accompanied by impaired barrier function. Special attention shall be paid to ICD, which is a non-immunologic and non-specific inflammatory disorder caused by external challenges (Tan et al., 2014), since it is a frequent occupational disease affecting workers in healthcare, food- and cosmetic industry (Schwensen et al., 2013). It is known that vehicles and additives used for dermal or transdermal medication may also lead to irritation (Gloor, 2004; Erős et al., 2014). In the mentioned diseases, barrier disruption is characterized by increased transepidermal water loss (TEWL) and decreased SC hydration (Thune et al., 1988, Proksch et al., 2006). Moreover, signs of inflammation can be detected. Thus, it is practical to supplement external formulations with agents that can provide protection against irritation and help maintain the skin's homeostasis.

Glycerol is a well-known example of such a compound. This polyol exerts potent antiirritant effect (Andersen et al., 2007) and increases the water content of SC via different mechanisms (Fluhr et al., 2008). It is known that glycerol, as a humectant, is able to retain water in the SC (Rawlings et al., 2004). Another mechanism is the interaction of glycerol with SC lipids and proteins which changes their water-binding properties, and glycerol also prevents the phase transition of SC lipids from liquid to solid crystalline structure (Froebe, 1990; Appa et al., 1993). Furthermore, glycerol reduces the average aqueous pore radius in the SC, hereby decreasing water loss and hampering the penetration of irritants (Ghosh \& Blankschtein, 2007). Glycerol also displays keratolytic effect, stabilizes skin collagen and accelerates wound healing (Fluhr et al., 2008). Considering these advantageous properties of glycerol, it may be assumed that also other polyols may have similar beneficial effects. 
Xylitol is a naturally occurring polyol found in the fibers of many fruits and vegetables. It is used as sweetener for diabetic persons. Its energy content is lower than that of most carbohydrates and can be taken up by the cells without insulin. Furthermore, oral administration of xylitol has been shown to diminish bone resorption in animal model (Mattila et al., 1995). Xylitol can also enhance the liberation of antibiotics from polymerbased carrier systems thereby improving the therapy of chronic osteomyelitis (Beenken et al., 2012). Moreover, xylitol can be utilized as an active agent as well: the polyol was found to inhibit the proliferation of Streptococcus mutans in the oral cavity thus can contribute to the prevention of caries (Loesche et al., 1984, Ly et al., 2006). Since xylitol has considerable humectant effect (Cohen et al., 1993, Leite e Silva et al., 2009), it seems to be able to hydrate the skin in vivo.

Mannitol is a sugar alcohol similar to xylitol. Its main clinical application is the reduction of acutely increased intracranial pressure. However, neither xylitol nor mannitol has yet been used in local formulations in order to prevent irritation.

Nevertheless, polyols are not the only promising antiirritant candidates, amino acids also contribute to the homeostasis of the skin. Natural moisturizing factor (NMF), which is a cornerstone of skin hydratation, contains amino acids at high ratio (Harding $\&$ Scott, 2002, Rawlings \& Harding, 2004). Mixtures of amino acids are used for skin revitalization (Sparavigna et al., 2015). Less information is available on efficacy of separately applied amino acids. However, some of them seem to be appropriate to ameliorate skin irritation. Taurine, a sulfur-containing amino acid, is an organic osmolyte. In the skin, it exhibits antioxidant effects, protects cells from ultraviolet (UV)-induced stress and acts on cell proliferation, inflammation and collagenogenesis (Warskulat et al., 2004, Anderheggen et al., 2006). Keratinocytes express specific taurine transporter (TauT) which facilitates taurine uptake of cells thereby providing protection against hyperosmotic stress and other challenges (Grafe et al., 2004, Rockel et al., 2007).

Glycine, another amino acid of importance in dermatologic therapy, is traditionally used for the treatment of scars and has beneficial effects on the skin reparation process and the overall rate of wound healing (Marrubini et al., 2008).

Methionine was reported to provide protection against reactive oxygen species (ROS) (Wu et al., 2012). Moreover, unpublished in vitro data suggest that methionine may be able to decrease the activity of matrix metalloproteinase-1 (MMP-1). This enzyme plays a pivotal role in photoaging (Quan et al., 2009). 
It shall also be considered that different antiirritant agents may have synergistic and complementary effects. Although glycerol and xylitol have similar chemical structure, these polyols induce different gene expression changes in the keratinocytes. In vitro experiments have demonstrated that glycerol decreases the expression of human leukocyte DR (HLA-DR), thereby reducing inflammation, while xylitol increases the expression of filaggrin (SzabóPapp et al., 2012). As a source of NMF and also in other ways, filaggrin contributes to the hydration and homeostasis of the skin (Harding et al., 2013). Induction of filaggrin expression, which leads to the hydration of the skin, can be accompanied by the suppression of MMP-1 (Cho et al., 2011), thereby contributing to skin rejuvenation. Previous animal experiments of our working group have revealed that both glycerol and xylitol possess antiinflammatory effects, but they influence the expression of inflammatory cytokines in different ways (Szél et al., 2015).

Moreover, combination of xylitol with farnesol was reported to reduce the colonization of skin by Staphylococcus aureus (S. aureus) and to hydrate atopic dry skin (Katsuyama et al., 2005a). Thus, combination of polyols, especially that of glycerol and xylitol, may enhance their beneficial effects.

Another important question is the duration of treatment period and the optimal concentration of the applied polyols and amino acids. Since glycerol is a widely used antiirritant compound, plenty of data has been published on its local application. In irritated skin, glycerol improves hydration even in 15-30 min (Atrux-Tallau et al., 2010). Another study found that SC hydration shows the highest values after 3 days of treatment with glycerol (Fluhr et al., 1999). However, different periods of application may be needed in order to influence other dermatophysiological parameters. For instance, skin barrier repair requires at least 3 days (Fluhr et al., 1999, Gloor \& Gehring, 2001). Positive impact of glycerol seems to correlate with its concentration. In terms of skin hydration, glycerol concentrations of $2-10 \%$ were found to be effective (Atrux-Tallau et al., 2010). However, animal experiments suggest that concentrated glycerol may impair dermal microcirculation (Zaman et al., 2009). As concerns the other polyols and amino acids, the optimal time of their application and their effective concentrations require investigation.

For assessment of skin barrier function and for testing the efficacy of barrier-improving agents, TEWL and skin hydration are widely used (du Plessis et al., 2013). TEWL represents the diffusion of condensed water through the SC (Rogiers, 2001, Imhof et al., 2009). This parameter can be determined by different instruments (Proksch et al., 2008, du Plessis et al., 2013). Alterations of TEWL and skin hydration may be accompanied by changes in skin's 
mechanical properties, as well (Lee et al., 2011). Thus, monitoring of biomechanical parameters of the skin (e.g. viscoelasticity, skin smoothness, etc.) may provide useful information on the efficacy of the applied treatments.

For investigation of ICD and skin barrier recovery, sodium lauryl sulfate (SLS)-induced irritation is a frequent method. SLS, an anionic detergent, is a common surfactant accepted as a reference irritant (Agner \& Serup, 1989, Lee \& Maibach, 1995). It is suitable for irritant patch testing because of its ability to influence the barrier function of the skin and to cause inflammation. Exposure to SLS results in an increased TEWL and in epidermal hyperproliferation. A linear relationship between the dose of SLS and the skin's response has been demonstrated both by visual scoring and by bioengineering techniques (Agner \& Serup, 1990). These data drew our attention to the potential antiirritant effects of polyols and amino acids and served as a guideline for the design of our studies.

\subsection{AIMS}

Our principal goal was to study the effects of locally applied polyols and amino acids on the barrier function, the hydration, the biomechanical-, the morphological- and the microbiological parameters of the human skin. For this aim, human studies and in vitro experiments were designed. The entire study was divided into 3 consecutive parts (mentioned as Study I, Study II and Study III, respectively).

In Study I, the major objectives were:

- to create a model of mild (subclinical) irritation using SLS as irritant,

- to examine the antiirritant properties of glycerol, xylitol, mannitol, taurine and glycine by measurement of TEWL,

- and to find the effective concentrations of the above mentioned agents.

In Study II, it was set out:

- to study the antibacterial effects of a glycerol- and xylitol-containing combination product in vitro and in vivo,

- and to monitor its impact on TEWL, skin hydration and skin $\mathrm{pH}$.

The goals of Study III were:

- to observe the effects of the mentioned glycerol- and xylitol-containing formulation on TEWL, skin hydration, biomechanical parameters and morphology after a longer period of application (14 days),

- to study the effects of locally applied methionine on these parameters, 
- and to identify the protein quantities of filaggrin and MMP-1 after these treatments.

\section{MATERIALS AND METHODS}

\subsection{MATERIALS}

SLS ( $>99 \%$ purity) was obtained from Huntsman Corp. (Salt Lake City, UT, USA), glycerol was purchased from Cognis (Dusseldorf, Germany), xylitol, L-methionine and Carbopol Ultrez 10 from Sigma Aldrich Corp. (St Louis, MO, USA), D-mannitol from Roquette Frères (Lestrem, France) while taurine and glycine from Merck (Darmstadt, Germany). The quality of all these compounds met the European Pharmacopoeia (Ph Eur 5) standards. In Study II, the applied Xylinep ${ }^{\circledR}$ gel (containing 0.4\% Carbopol Ultrez 10, 5\% glycerol and 5\% xylitol) was produced by Pannon Pharma Ltd. (Pécsvárad, Hungary). The formulations for Study III were prepared by the Central Pharmacy, University of Szeged. The rabbit polyclonal antihuman filaggrin antibody (catalogue no: AB24584) and the rabbit monoclonal anti-human MMP-1 antibody (clone EP 1247Y, catalogue no: AB52631) were from Abcam Ltd. (Cambridge, UK).

\subsection{SUBJECTS AND ETHICAL CONSIDERATIONS}

All parts of the study were approved by the local institutional ethics committee for human biomedical trials at the University of Szeged. (Permission numbers: Study I: No. 2078, 2216; Study II: 135/2012; Study III: No. 3353 2014-03-10, CSR/039/00426-5/2014.) All subjects participated only after receiving detailed oral and written information and signing an informed consent agreement. Exclusion criteria were: (1) major skin-, endocrine- or immune system diseases, (2) pregnancy or breast feeding, (3) systemic corticosteroid or cytostatic therapy within 30 days, (4) any use of local drugs that might influence the skin's texture or reactivity, (5) any condition on the study sites that could interfere with a clear-cut assessment of the skin, and (6) current participation in any other clinical study. For Study III, inclusion criteria were low hydration values ( $\leq 25$ A.U.) on the inner upper arms, measured with a Corneometer CM 825 (Courage+Khazaka electronic GmbH, Cologne, Germany).

Study I involved 16 volunteers (aged 20 to 65 years), 15 volunteers (age: 18-65 years) were recruited for Study II, while Study III involved 12 volunteers, aged 50-60 years. 


\subsection{SKIN PHYSIOLOGICAL MEASUREMENTS}

The investigations were performed in the Cosmetological and Skin-Physiological Research Laboratory of the Department of Dermatology and Allergology, University of Szeged. Room conditions were controlled; the relative humidity was $40-50 \%$, and the ambient temperature was kept at $20-22{ }^{\circ} \mathrm{C}$. All measurements were performed after a 15-20 min relaxation period. The extent of hydration of the skin surface was measured with a Corneometer CM 825 . TEWL was determined with a Tewameter TM 300 (Courage + Khazaka electronic GmbH, Cologne, Germany). pH of the skin surface was assessed with a Skin pH-Meter PH 905 (Courage + Khazaka electronic GmbH, Cologne, Germany). The skin friction was monitored with a Frictiometer FR 700 (Courage + Khazaka electronic GmbH, Cologne, Germany). A Cutometer MPA 580 (Courage + Khazaka electronic GmbH, Cologne, Germany) was used to monitor the skin elasticity. R-parameters, calculated by the software of the device, were registered and compared. Furthermore, the skin was examined with a DUB-USB highfrequency, high-resolution ultrasound system (Taberna pro Medicum GmbH, Luneburg, Germany). A volume of $80 \mathrm{~dB}$ was used to take images which were evaluated off-line. Epidermal and dermal thicknesses and the echogenicity of the papillary dermis were measured by means of DUB-SkinScanner software.

\subsection{IN VITRO AND IN VIVO MICROBIOLOGICAL EXAMINATIONS}

For the in vitro experiments, S. aureus (ATCC 6538) and S. pyogenes (ATCC 19615) were chosen for test bacteria. As first step, fresh cultures were made from the frozen bacteria (TSB liquid culture medium was used for S. aureus and PPLO agar gel for S. pyogenes). Bacterium suspensions were then prepared by dilution of the cultures. The germ number of the S. aureus suspension was adjusted to be approximately $100000 \mathrm{CFU} / 100 \mu \mathrm{L}$ (3 bulk suspensions were made) while dilution of the S. pyogenes culture led to suspensions of $59 \mathrm{CFU} / 100 \mu \mathrm{L}$ and 590 CFU/100 $\mu$ L. Subsequently, the above mentioned Xylinep ${ }^{\circledR}$ gel was inoculated with the bacteria. $1 \mathrm{~g}$ of Xylinep ${ }^{\circledR}$ gel was weighed out and added into sterile, closable plastic tubes of $5 \mathrm{~mL}$ in a sterile box using sterile devices. (The gel cannot be pipetted, it was dosed with a small-sized chemical spoon.) Bacterium suspension was added to the gel, and then it was mixed with a sterile toothpick and vortex, as well. The gels inoculated with the test bacteria were incubated at $25{ }^{\circ} \mathrm{C}$ for 24 and 48 hours. (In the experiments with S. aureus, 2-2 parallel gel tests were carried out.) After incubation, the 1-gram gel portions inoculated with the bacteria were dissolved in $9 \mathrm{~mL}$ of sterile distilled water. From this, series of dilutions were made. In case of S. aureus, $100 \mu \mathrm{L}$ from the members of the dilution was pipetted onto TSA 
plates. After incubation at $35^{\circ} \mathrm{C}$ for 24 and 48 hours, the germ numbers were estimated on the plates. When working with S. pyogenes, PPLO plates were used and the incubation time came to 72 hours. As control, 1-1 grams of the gel was diluted and pipetted onto plates immediately after incubation with the bacteria in order to estimate initial germ numbers in the gel.

Concerning in vivo investigation, a sterile glass ring of $3 \mathrm{~cm}$ in diameter was placed onto the arms of the examined persons. Into the sterile ring, $500 \mu \mathrm{L}$ of sterile PBS, containing $0.1 \%$ Treton-X, was weighed in and then $100 \mu \mathrm{L}$ of it was spread on blood agar culture medium. This was considered as starting, i.e. baseline value. The area of $3 \mathrm{~cm}$ was marked and it was smeared with the Xylinep ${ }^{\circledR}$ gel. The applied gel quantity was absorbed within 15 minutes. The described examination: placing of sterile ring, sample taking and spreading on blood agar culture medium were then performed again in order to monitor the antibacterial effect of the gel. (The culture media after each sample taking were placed into a thermostat of $37^{\circ} \mathrm{C}$ and colonies were counted after 24 hours of incubation.) After that, the subject continued treatments on the marked areas: the gel was applied in the morning and in the evening. The treatment was carried out 6 times in total. 2 hours after the $6^{\text {th }}$ treatment, i.e. 74 hours after the beginning of the study, samples were taken, as described.

\subsection{STUDY DESIGN}

Study I:

The ventral side of the forearm was used as test region. In closed patch tests using extra-large Finn Chambers with a diameter of $18 \mathrm{~mm}$ (Epitest, Helsinki, Finland) on Scanpor tape (Norgesplaster A/S, Vennesla, Norway) and corresponding filter discs, $200 \mu \mathrm{L}$ of a $0.1 \%$ aqueous solution of SLS was applied to the test chamber and left for 24 hours on one forearm, as recommended in previous studies (Tupker et al., 1997, Tupker et al., 2005). The test chamber on the corresponding site on the other forearm contained $0.1 \%$ SLS solution supplemented with one or another of the study agents in the concentrations listed in Table $\mathbf{1 .}$ Test chambers were removed after 24 hours. TEWL was measured before patch application and 30 minutes after removal of the test chambers and the rinsing and drying of the test areas. 
Table 1. Study agents and their applied concentrations in Study I

\begin{tabular}{|c|c|}
\hline Study agent & Applied concentrations (\%) \\
\hline Glycerol & $2.6,9.0$ \\
\hline Xylitol & $4.5,15.0$ \\
\hline D-mannitol & $5.4,18.0$ \\
\hline Taurine & $3.4,8.4$ \\
\hline Glycine & 5.0 \\
\hline
\end{tabular}

Study II:

This part of our investigation involved in vitro experiments and in vivo examinations in order to assess the antibacterial effect of glycerol and xylitol (Xylinep ${ }^{\circledR}$ gel). (These are described in chapter 3.4.). Furthermore, effects of the gel on different skin physiological parameters were also detected. Skin hydration, TEWL and skin $\mathrm{pH}$ were measured. After determining the baseline values, an area of $4 \times 4 \mathrm{~cm}$ was marked on the forearm and was exposed to Xylinep ${ }^{\circledR}$ gel. Measurements were performed after 2, 8, 12 and 24 hours.

Study III:

Four $2 \times 2 \mathrm{~cm}$ areas were marked out on both lateral upper arms. Area 1 served as untreated control. Area 2 received the vehicle (Carbopol Ultrez 10 0.4\%, dissolved in purified water). A gel containing 5\% xylitol and 5\% glycerol (dissolved in the above-mentioned vehicle) was applied to area 3, while area 4 was exposed to $2 \%$ of L-methionine (in the same vehicle). 2 treatments were applied daily for 14 days. Measurements were performed twice: the studied parameters were determined before the first application of the preparations and on day 14, 6 hours after the last treatment. The following parameters were monitored: skin hydration, TEWL, skin friction, skin elasticity and images were also taken by means of high-frequency, high resolution ultrasound system. Finally, full-thickness skin biopsies were taken from each area with a 4-mm circular blade ("punch biopsy") under local anaesthesia. The wounds were then closed with a single suture.

The study design is summarized in Figure 1. 


\section{Study I:}

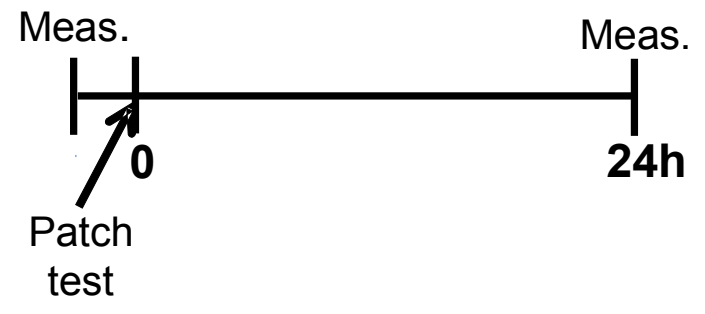

\section{Study II:}
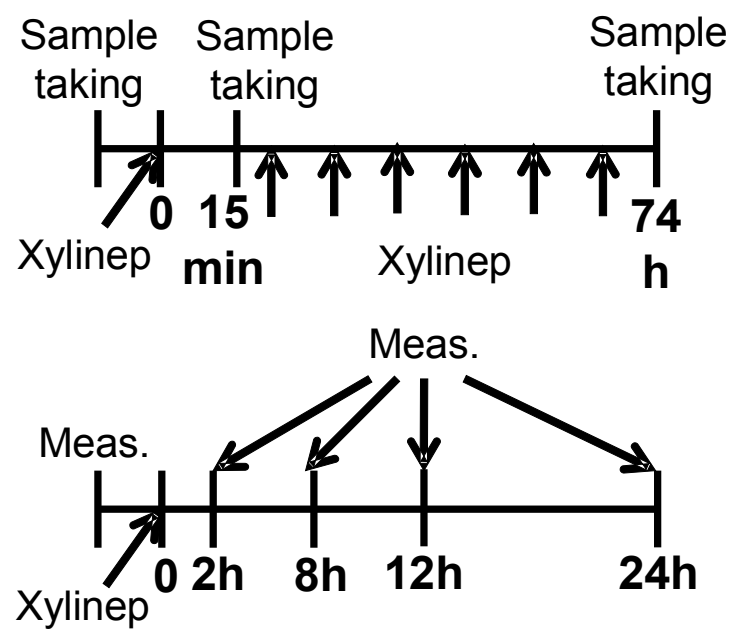

Meas.: Measurement of TEWL

Patch test: application of polyols and amino acids of different concentrations (see Table 1) in Finn Chambers

Sample taking: obtaining small portion from the sterile solution contacting the skin for microbiological examination (see chapter 3.4.) Xylinep: a formulation containing glycerol (5\%) and xylitol (5\%)

Meas.: determination of TEWL, skin $\mathrm{pH}$ and skin hydration

\section{Study III:}

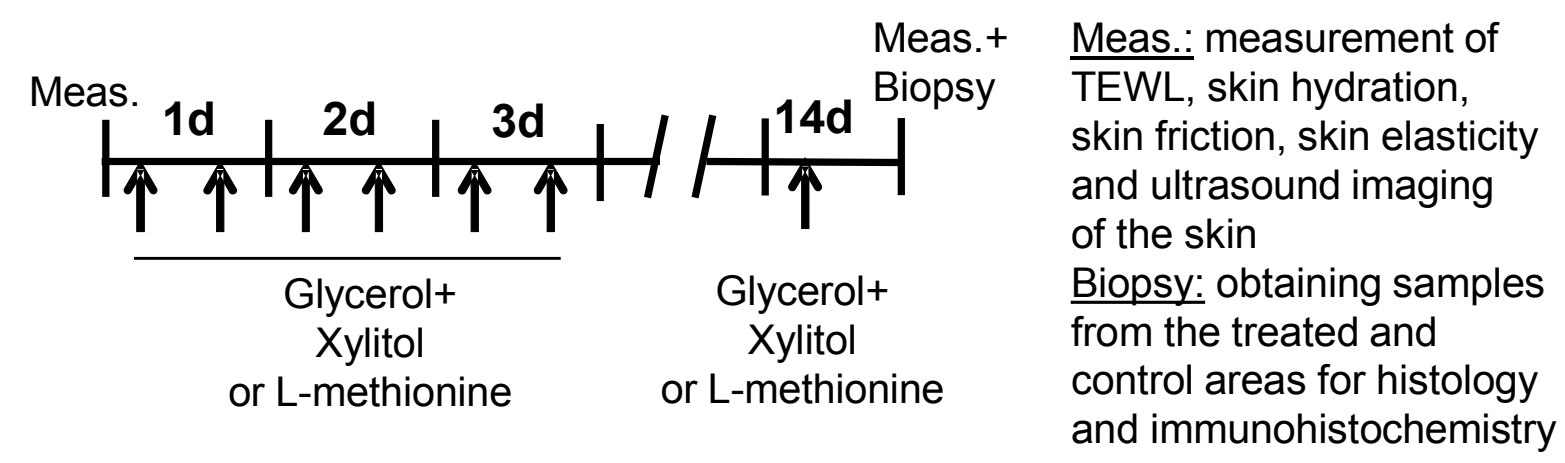

Figure 1. Measurements, treatments and interventions carried out in Study I, Study II and Study III, respectively. 


\subsection{HISTOLOGY AND IMMUNOHISTOCHEMISTRY}

Tissue samples obtained in Study III with the biopsy were fixed in a buffered solution of formaldehyde (4\%), embedded in paraffin and 3- $\mu \mathrm{m}$ thick coded slides were made. One slide was stained with haematoxylin-eosin $(\mathrm{H} \& \mathrm{E})$, while the others were subjected to immunohistochemistry by means of a Leica BOND-MAX autostainer (Leica Biosystems, Nussloch, Germany). Retrieval was performed at $\mathrm{pH}=6$ at $100^{\circ} \mathrm{C}$ for 20 minutes. Filaggrin antibody was used in 1:1000 dilution, and MMP-1 antibody in 1:50 dilution. Both antibodies were applied for 20 minutes. A Bond Polymer Refine Detection Kit (Leica Biosystems) was then used; the sections were exposed to 3,3'-diaminobenzidine (DAB) for 10 minutes, followed by counterstaining with haematoxylin.

All slides were scanned and analysed with Pannoramic Viewer software (3D Histec, Budapest, Hungary). In the H\&E-stained sections, the interdigitation index was determined, as described by Timár et al. (Timár et al., 2000). Briefly, the length of the line following the interdigitation between 2 points on the border between the epidermis and the dermis was divided by the length of a straight line between the same 2 points in order to calculate the interdigitation index. In the filaggrin-stained slides, the percentage of epidermal cells showing positive staining was determined. For the characterization of the quantity of MMP-1 protein, a semi-quantitative scoring system was used: 1: mild, 2: moderate, 3 : expressed positivity in the epidermis.

\subsection{STATISTICAL ANALYSIS}

Statistical analysis was performed with the SigmaStat for Windows statistical software package (Jandel Scientific, Erkrath, Germany). The Shapiro-Wilk test was used to check normality. In terms of a few parameters in Study III, the values obtained varied significantly from the pattern expected if the data were drawn from a population with a normal distribution. In Study III, non-parametric methods were therefore used. The Wilcoxon signed-rank test was applied to compare data obtained before and after the treatments. The differences between the treatments were analysed with the Kruskal-Wallis one-way analysis of variance on ranks, followed by Dunn method for pairwise multiple comparison. In Figures 10-13, 15-17, 19 and 21 , median values with the $25^{\text {th }}$ and $75^{\text {th }}$ percentiles are given; $\mathrm{p}<0.05$ and $\mathrm{p}<0.001$ were considered statistically significant.

Data obtained in Study I and Study II passed the normality test. Thus, in Study I, the paired ttest was performed for comparison within groups (TEWL before and after the application of patch-test chambers with SLS or SLS plus polyol or amino acid). For comparison between 
groups (different concentrations of study agents and postpatch TEWL values at untreated and treated sites), the two-sample t-test was applied. A level of $p<0.05$ was considered statistically significant. The reported data are mean values (m) plus or minus standard deviation (SD). (Figures 2-6)

In Study II, one-way repeated measures analysis of variance with the Holm-Sidak test was used. A level of $p<0.05$ was considered statistically significant. The appropriate Figures (Figures 7-9) depict m values with SD.

\section{RESULTS}

\subsection{STUDY I}

\subsubsection{EFFECTS OF POLYOLS ON SKIN IRRITATION}

Exposure of the skin to a $0.1 \%$ solution of SLS led to a statistically significant increase in TEWL relative to the baseline in all experiments. The addition of glycerol at $2.6 \%$ to the SLS did not prevent skin irritation; there was still a significant difference between TEWL values before patch application $(\mathrm{m}=7.78, \mathrm{SD}=3.3)$ and $\mathrm{TEWL}$ values after patch application $(\mathrm{m}=12.06, \mathrm{SD}=7.71)$. However, glycerol at $9 \%$ was effective in protection against irritation; TEWL values before patch testing $(\mathrm{m}=12.17, \mathrm{SD}=6.32)$ and after patch testing $(\mathrm{m}=13.16$, $\mathrm{SD}=4.77$ ) did not differ statistically. Furthermore, this concentration of glycerol considerably reduced TEWL on the treated site $(\mathrm{m}=13.16, \mathrm{SD}=4.77)$ as compared to the untreated (but irritated) site $(\mathrm{m}=20.39, \mathrm{SD}=10.0)$ (Figure 2).

Xylitol also was applied in two concentrations: $4.5 \%$ and $15 \%$. The lower concentration failed to provide protection against irritation (before application: $\mathrm{m}=6.06, \mathrm{SD}=2.85$; after: $\mathrm{m}=11.43$, $\mathrm{SD}=4.59$ ). However, the higher concentration effectively prevented the elevation of TEWL (before: $\mathrm{m}=9.01, \mathrm{SD}=3.51$; after: $\mathrm{m}=11.94, \mathrm{SD}=6.69$ ). Nevertheless, no significant difference was found between untreated sites $(\mathrm{m}=13.14, \mathrm{SD}=5.09)$ and treated sites $(\mathrm{m}=11.94, \mathrm{SD}=6.69)$ after the application of SLS (Figure 3).

The application of mannitol at concentrations of either $5.4 \%$ or $18 \%$ was not effective in reducing the SLS-induced increase in TEWL (mannitol at 5.4\%: $\mathrm{m}=15.71, \mathrm{SD}=3.22$ before, $\mathrm{m}=25.92, \mathrm{SD}=3.19$ after; mannitol at $18 \%: \mathrm{m}=15.4, \mathrm{SD}=4.64$ before, $\mathrm{m}=22.99, \mathrm{SD}=5.09$ after). However, mannitol at $18 \%$ led to significantly lower TEWL values after patch testing than SLS alone did (treated site: $\mathrm{m}=22.99, \mathrm{SD}=5.09$; untreated site: $\mathrm{m}=35.04, \mathrm{SD}=9.85$ ) (Figure 4). 


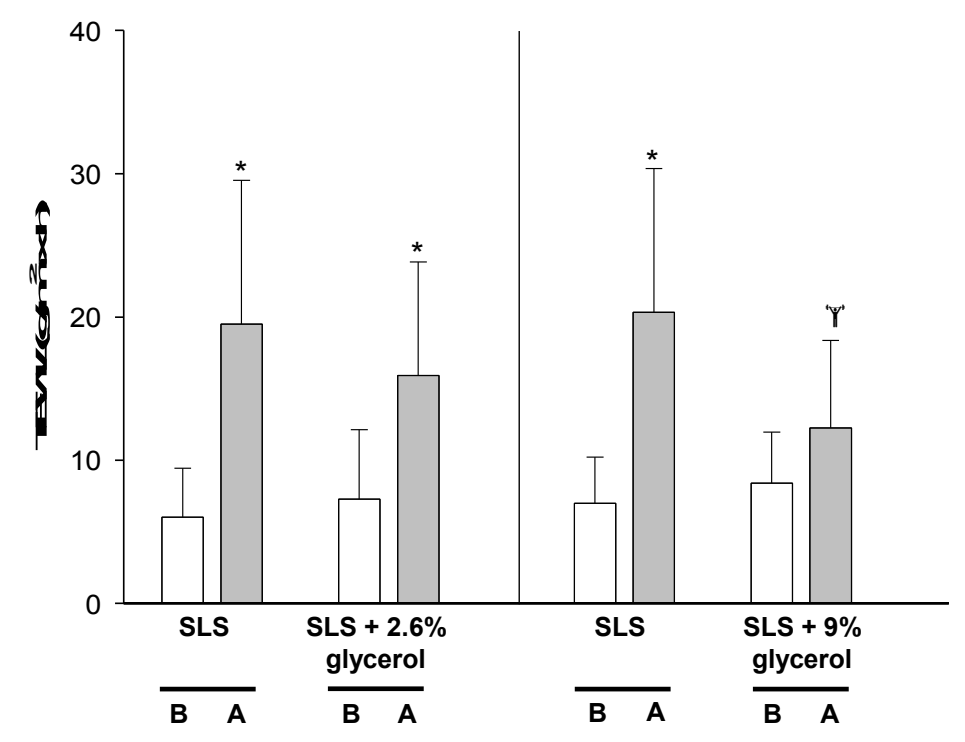

Figure 2. TEWL before and after exposure to SLS or SLS plus glycerol at $2.6 \%$ or $9 \%$. Values are given as $\mathrm{m} \pm$ SD. B: TEWL before application of the patch, A: TEWL after removal of the patch. *: $p<0.05$ vs TEWL before patch application; $\S: \mathrm{p}<0.05$ vs TEWL at untreated site.

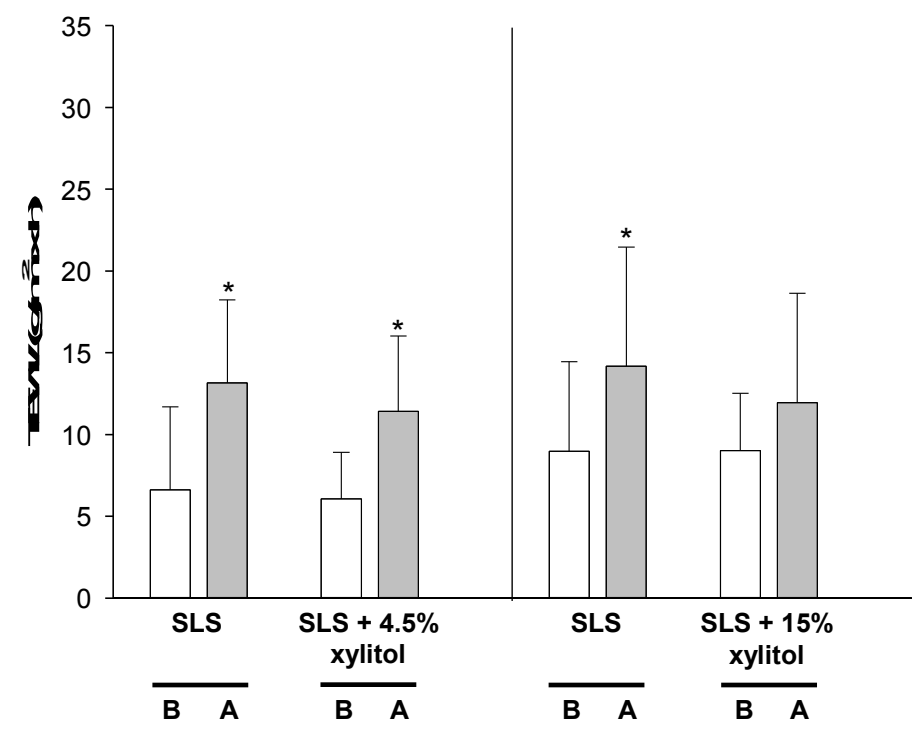

Figure 3. TEWL before and after exposure to SLS or SLS plus xylitol at $4.5 \%$ or $15 \%$. Values are given as $m \pm$ SD. B: TEWL before application of the patch, A: TEWL after removal of the patch. *: $p<0.05$ vs TEWL before patch application. 


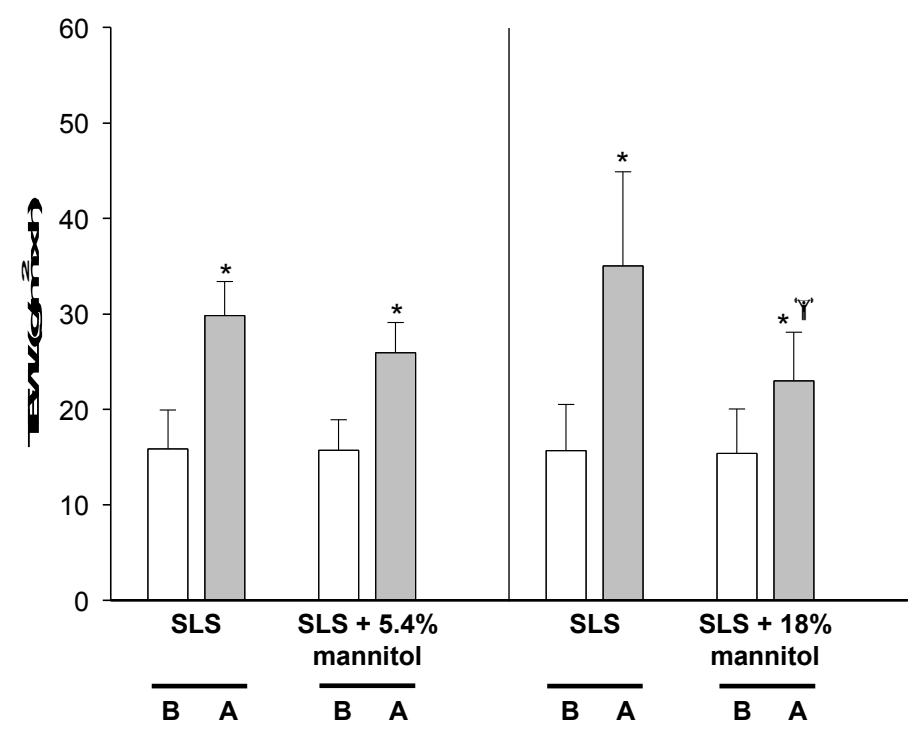

Figure 4. TEWL before and after exposure to SLS or to SLS plus mannitol at $5.4 \%$ or $18 \%$. Values are given as $\mathrm{m} \pm \mathrm{SD}$. B: TEWL before application of the patch, A: TEWL after removal of the patch. *: $\mathrm{p}<0.05$ vs TEWL before patch application; $\S: \mathrm{p}<0.05$ vs TEWL at untreated site.

\subsubsection{EFFECTS OF AMINO ACIDS ON SKIN IRRITATION}

Taurine at $3.4 \%$ did not lead to a great improvement in TEWL (before: $\mathrm{m}=14.29, \mathrm{SD}=3.38$; after: $\mathrm{m}=33.04, \mathrm{SD}=14.49$ ), and taurine at $8.4 \%$ also failed to inhibit the increase in TEWL (before: $\mathrm{m}=12.34, \mathrm{SD}=2.42$; after: $\mathrm{m}=23.53, \mathrm{SD}=5.57$ ). However, statistical analysis revealed that the TEWL level after the application of taurine at $8.4 \%$ was significantly lower than that observed for the $3.4 \%$ solution. Moreover, taurine at $8.4 \%$ also decreased TEWL $(\mathrm{m}=23.53$, $\mathrm{SD}=5.57)$ as compared to untreated site $(\mathrm{m}=31.18, \mathrm{SD}=12.56)$ (Figure 5.).

Glycine at 5\% did not provide protection against TEWL-elevation resulting from exposure to SLS (before: $\mathrm{m}=12.47, \mathrm{SD}=5.19$; after: $\mathrm{m}=24.23, \mathrm{SD}=12.47$ ). TEWL values at sites not treated with glycine $(\mathrm{m}=24.61, \mathrm{SD}=12.57)$ and at treated sites $(\mathrm{m}=24.23, \mathrm{SD}=12.47)$ did not differ significantly (Figure 6.). Lower concentrations of polyols and amino acids did not result in significant differences in TEWL values at untreated and treated sites after patch testing. 


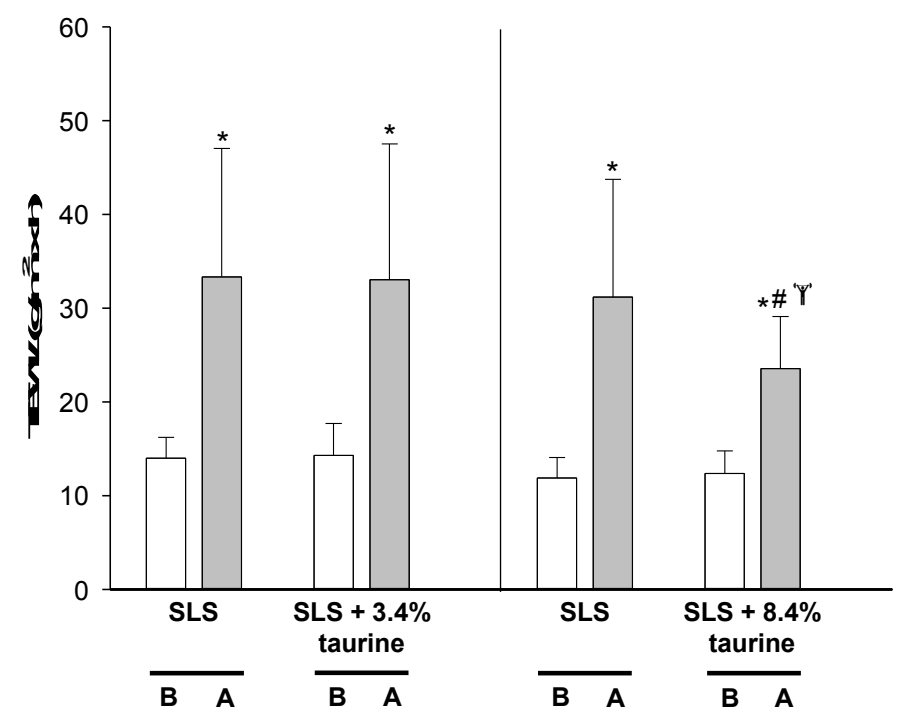

Figure 5. TEWL before and after exposure to SLS or to SLS plus taurine at $3.4 \%$ or $8.4 \%$. Values are given as $\mathrm{m} \pm \mathrm{SD}$. B: TEWL before application of the patch, A: TEWL after removal of the patch. *: $\mathrm{p}<0.05$ vs TEWL before patch application; \#: $\mathrm{p}<0.05$ vs TEWL after 24-hour exposure to SLS plus $3.4 \%$ taurine; $\S: \mathrm{p}<0.05$ vs TEWL at untreated site.

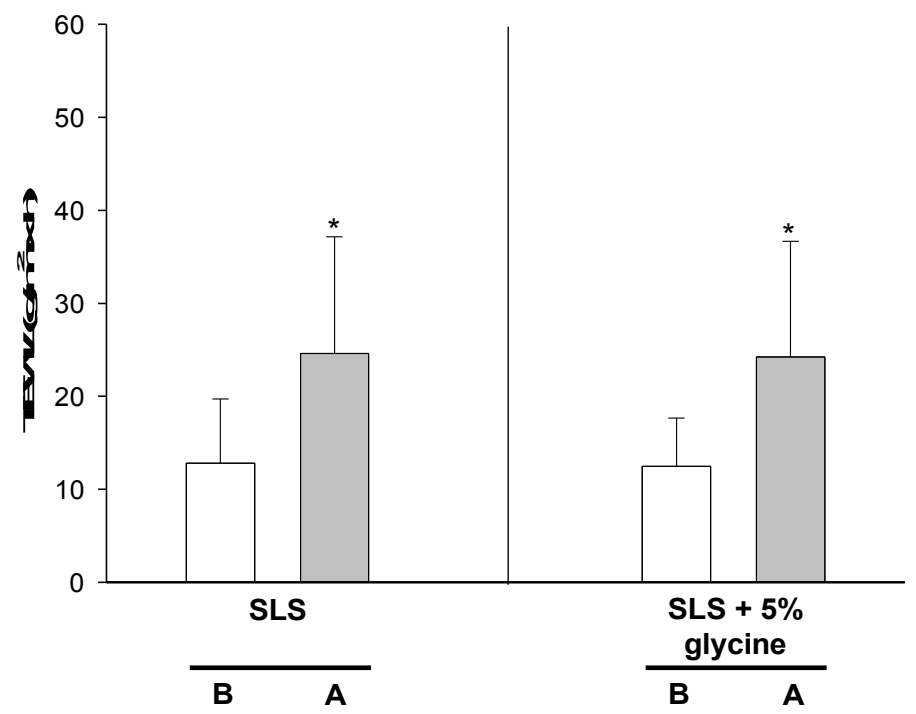

Figure 6. TEWL before and after exposure to SLS or SLS plus glycine at 5\%. Values are given as $m \pm S D$. B: TEWL before application of the patch, A: TEWL after removal of the patch. *: $p<0.05$ vs TEWL before patch application. 


\subsection{STUDY II}

\subsubsection{IN VITRO AND IN VIVO ANTIBACTERIAL EFFECTS OF POLYOLS}

The effects of the glycerol- and xylitol-containing Xylinep ${ }^{\circledR}$ gel on S. pyogenes cultures are summarized in Table 2. When the gel was inoculated with the S. pyogenes suspensions, no viable bacteria were detected from the suspension of lower bacterial concentration while few bacteria were found from that of higher bacterial concentration.

Table 2. Survival of S. pyogenes after exposing the bacterial suspensions to Xylinep ${ }^{\circledR}$ gel

\begin{tabular}{|l|l|l|}
\hline \multirow{2}{*}{ Initial bacterial concentration } & \multicolumn{2}{|c|}{ Number of colonies after exposure of } \\
\cline { 2 - 3 } & $24 \mathrm{~h}$ & $48 \mathrm{~h}$ \\
\hline $59 \mathrm{CFU} / 100 \mu \mathrm{L}$ & 0 & 0 \\
\hline $590 \mathrm{CFU} / 100 \mu \mathrm{L}$ & 16 & 13 \\
\hline
\end{tabular}

The antibacterial effect of the Xylinep ${ }^{\circledR}$ gel on S. aureus suspensions is demonstrated in Figure 7. The initial germ numbers of the applied suspensions (3 suspensions were produced) were found to be $121000 \mathrm{CFU} / 100 \mu \mathrm{L}, 125000 \mathrm{CFU} / 100 \mu \mathrm{L}$ and $54000 \mathrm{CFU} / 100$ $\mu \mathrm{L}$, respectively. Bacterial concentrations in the control samples (which were taken immediately after the inoculation) came to somewhat lower, but statistically no difference was found (108 $000 \mathrm{CFU} / \mathrm{g}, 124000 \mathrm{CFU} / \mathrm{g}, 53200 \mathrm{CFU} / \mathrm{g}$, respectively). However, considerable decrease was observed in the germ numbers after incubation of 24 hours (germ numbers of the 2-2 parallel gels: $27200 \mathrm{CFU} / \mathrm{g}, 38500 \mathrm{CFU} / \mathrm{g}$, and $61800 \mathrm{CFU} / \mathrm{g}, 39600 \mathrm{CFU} / \mathrm{g}$, and $29750 \mathrm{CFU} / \mathrm{g}, 5000 \mathrm{CFU} / \mathrm{g}$, respectively). After an incubation of 48 hours, no bacterial growth was detected.

As concerns in vivo antibacterial effect of Xylinep ${ }^{\circledR}$ gel, several bacteria was found on the skin of the subjects prior to the treatment (colony numbers: $m=53.27, \mathrm{SD}=100.87$ ). Local application of Xylinep ${ }^{\circledR}$ gel resulted in a significant fall in colony numbers even after 15 minutes $(\mathrm{m}=7.47, \mathrm{SD}=7.73)$. An expressed antibacterial effect was observed after 74 hours $(\mathrm{m}=15.27, \mathrm{SD}=20.38)$. (Figure 8) 


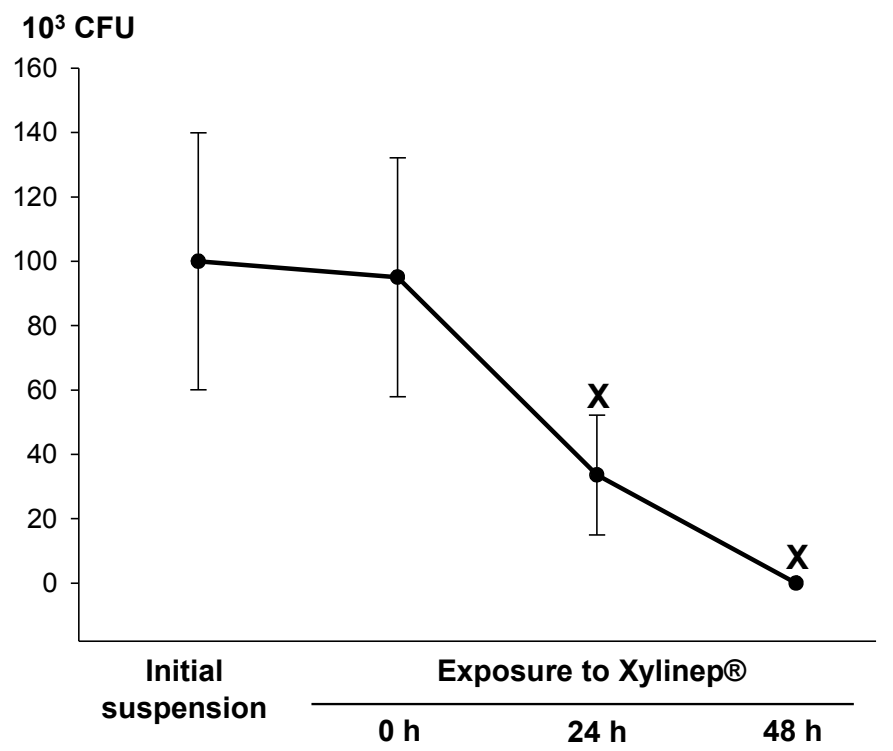

Figure 7. Effects of Xylinep ${ }^{\circledR}$ gel on suspensions of $S$. aureus. Values are given as $m \pm S D$. X: $p<0.05$ vs initial suspension.

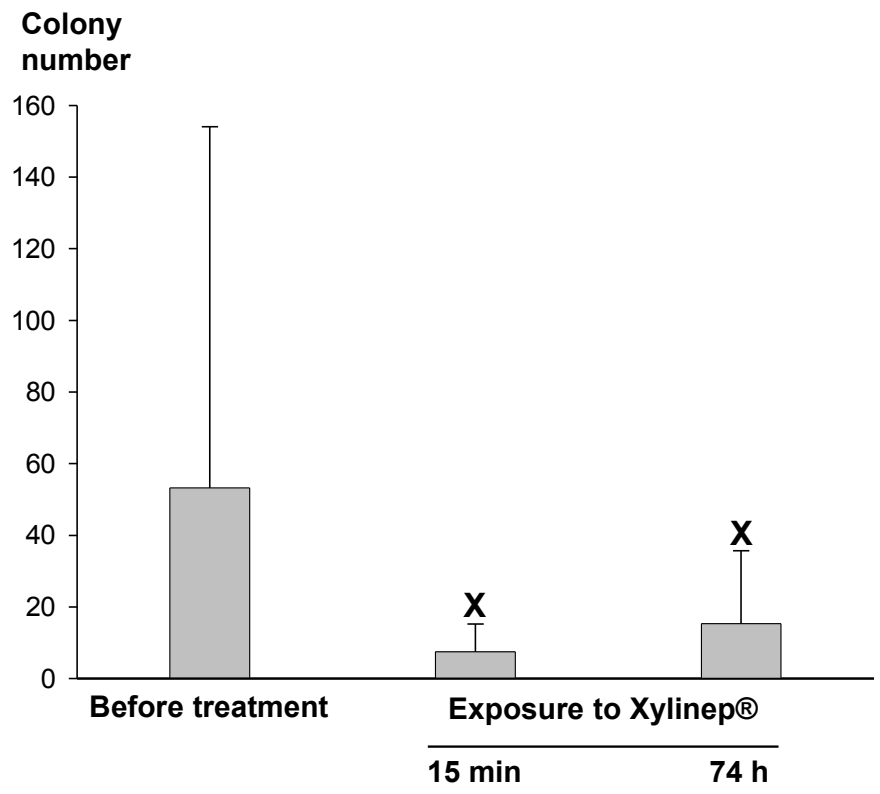

Figure 8. Number of colonies grown from the buffer contacting the subjects' skin before and after exposure to Xylinep ${ }^{\circledR}$ gel. Values are given as $\mathrm{m} \pm \mathrm{SD}$. X: $\mathrm{p}<0.04$ vs "Before" values. 


\subsubsection{EFFECTS OF POLYOLS ON SKIN PHYSIOLOGICAL PARAMETERS WITHIN 24}

\section{HOURS}

Application of Xylinep ${ }^{\circledR}$ gel did not influence skin $\mathrm{pH}$ and TEWL values significantly during the 24 hours of observation (data not shown). Effects of the glycerol- and xylitol-containing Xylinep ${ }^{\circledR}$ gel on skin hydration are summarized in Figure 9. As compared to baseline $(0 \mathrm{~h})$ values $(\mathrm{m}=38.24, \mathrm{SD}=5.84)$, a considerable elevation in hydration values was detected after 2 hours $(\mathrm{m}=45.83, \mathrm{SD}=9.86)$. The highest hydration values were measured after 8 hours $(\mathrm{m}=48.45, \mathrm{SD}=7.29)$. Furthermore, skin hydration values surpassed baseline values after 12 and 24 hours, as well (12h: $\mathrm{m}=46.9, \mathrm{SD}=7.34 ; 24 \mathrm{~h}: \mathrm{m}=42.52, \mathrm{SD}=8.69)$.

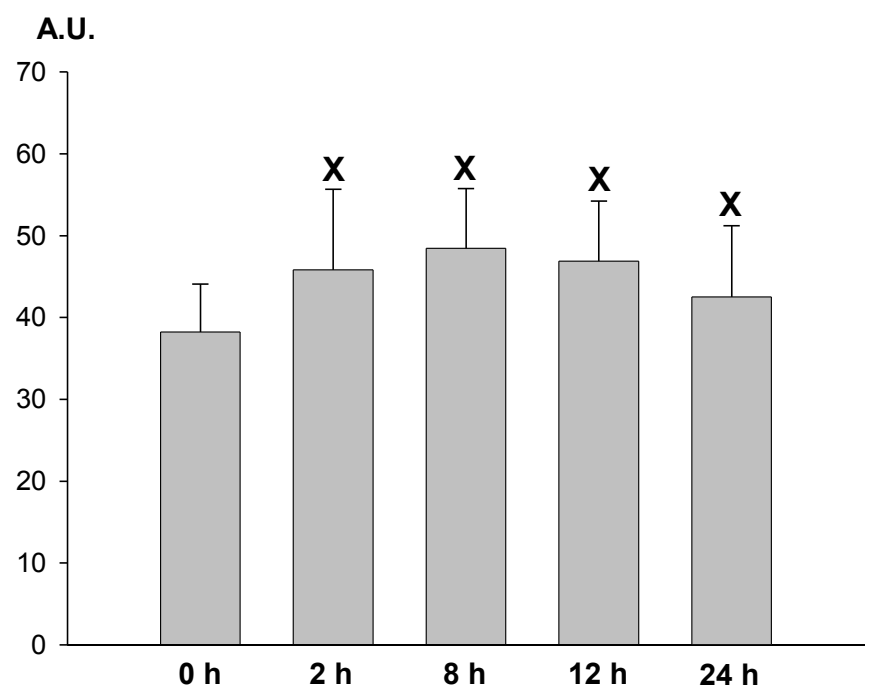

Figure 9. Changes in skin hydration after application of $X y l i n e p{ }^{\circledR}$ gel. Values are given as $m \pm S D . X: p<0.05$ vs $0 \mathrm{~h}$ values.

\subsection{STUDY III}

\subsubsection{EFFECTS OF POLYOLS ON SKIN PHYSIOLOGICAL PARAMETERS WITHIN 14} DAYS

Statistical analysis did not reveal any difference between the day 0 values for different areas in terms of any studied skin physiological parameter. The data demonstrate that the skin hydration did not display considerable changes in the control area (control: day 0: $M=20.45$, $25 \mathrm{p}=17.49,75 \mathrm{p}=24.39$, day $14: \mathrm{M}=22.18,25 \mathrm{p}=18.68,75 \mathrm{p}=27.89)$. The vehicle appeared to exert some skin-hydrating effect (vehicle: day 0 : $M=17.94,25 \mathrm{p}=16.39,75 \mathrm{p}=23.8$, day 14 : 
$\mathrm{M}=25.05,25 \mathrm{p}=17.99,75 \mathrm{p}=32.39)$. However, glycerol and xylitol led to more expressed increase in hydration (glycerol + xylitol: day $0: \mathrm{M}=18.9,25 \mathrm{p}=16.18,75 \mathrm{p}=23.4$, day 14 : $\mathrm{M}=29.44,25 \mathrm{p}=24.9,75 \mathrm{p}=37.51)$. (Figure 10)

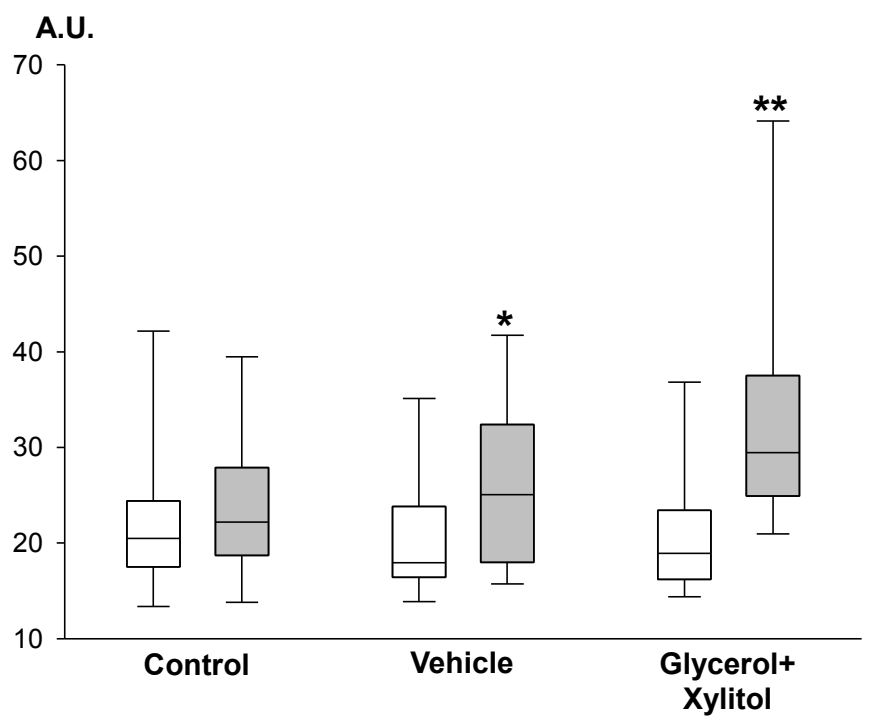

Figure 10. Skin surface hydration in non-treated, vehicle-treated and glycerol + xylitol treated areas, respectively. White box plots demonstrate the values determined on day 0 (before treatment), while the grey box plots represent the values measured on day 14 (after the treatment period). Median values (M) and the $25^{\text {th }}$ and $75^{\text {th }}$ percentiles are given. $*$ : $p<0.05$ vs day 0 values, $* *: p<0.001$ vs day 0 values.

The lack of treatment or exposure to vehicle did not alter the TEWL by the end of the observation period (control: day $0: \mathrm{M}=10.5,25 \mathrm{p}=8.45,75 \mathrm{p}=12.38$, day 14: $\mathrm{M}=8.65$, $25 \mathrm{p}=8.25,75 \mathrm{p}=10.13$, vehicle: day $0: \mathrm{M}=9.55,25 \mathrm{p}=6.95,75 \mathrm{p}=11.6$, day $14: \mathrm{M}=7.85$, $25 \mathrm{p}=6.08,75 \mathrm{p}=9.2$ ). Application of glycerol and xylitol significantly reduced the TEWL. Furthermore, the TEWL values of the areas exposed to the polyols were found to be considerably lower than those of the control areas on day 14 (glycerol + xylitol: day 0: $\mathrm{M}=11.3,25 \mathrm{p}=8.35,75 \mathrm{p}=12.18$, day $14: \mathrm{M}=5.45,25 \mathrm{p}=4.25,75 \mathrm{p}=7.9)$. (Figure 11) 


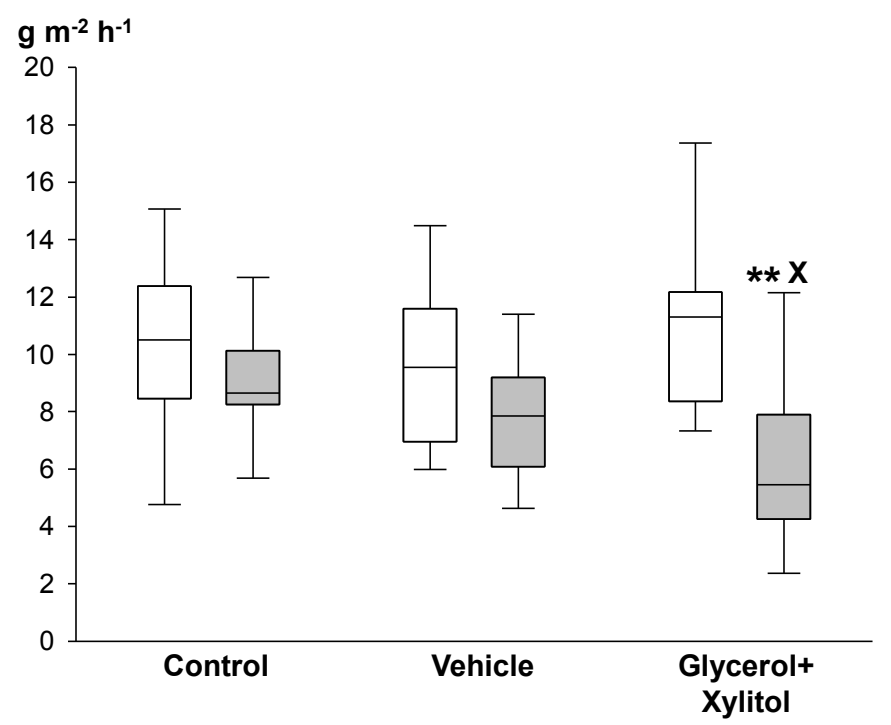

Figure 11. TEWL after exposure to no treatment, treatment to vehicle and treatment to glycerol + xylitol, respectively. White box plots demonstrate the values determined on day 0 (before treatment), while the grey box plots represent the values measured on day 14 (after the treatment period). Median values (M) and the $25^{\text {th }}$ and $75^{\text {th }}$ percentiles are given. $* *: \mathrm{p}<0.001$ vs day 0 values, $\mathrm{X}$ : $\mathrm{p}<0.05$ vs Control (non-treated).

The alterations in the biomechanical parameters are demonstrated in Figure 12 and Figure 13. Friction values measured after the use of vehicle were higher than day 0 data, but did not differ from the appropriate values of the control area (control: day $0: M=113.0,25 p=94.55$, $75 \mathrm{p}=131.1$, day $14: \mathrm{M}=126.9,25 \mathrm{p}=98.35,75 \mathrm{p}=144.3$, vehicle: day $0: \mathrm{M}=128.8,25 \mathrm{p}=93.8$, $75 \mathrm{p}=150.15$, day $14: \mathrm{M}=149.2,25 \mathrm{p}=138.6,75 \mathrm{p}=228.7)$. Treatment with glycerol and xylitol resulted in much more expressed elevations in friction values, which were also higher than those determined in the control area (glycerol + xylitol: day $0: M=138.1,25 p=100.95$, $75 p=183.3$, day 14: $M=241.8,25 p=207.05,75 p=742.05)$ (Figure 12).

As concerns the R-parameters determined with the Cutometer MPA 580, only R0 exhibited noteworthy changes. R0 values were significantly higher after the application of glycerol and xylitol for 14 days, the other preparation did not influence this parameter (control: day 0: $\mathrm{M}=0.199,25 \mathrm{p}=0.174,75 \mathrm{p}=0.255$, day $14: \mathrm{M}=0.205,25 \mathrm{p}=0.15,75 \mathrm{p}=0.224$, vehicle: day 0 : $\mathrm{M}=0.174,25 \mathrm{p}=0.156,75 \mathrm{p}=0.187$, day $14: \mathrm{M}=0.18,25 \mathrm{p}=0.15,75 \mathrm{p}=0.2$, glycerol + xylitol: day $0: \mathrm{M}=0.177,25 \mathrm{p}=0.165,75 \mathrm{p}=0.196$, day $14: \mathrm{M}=0.205,25 \mathrm{p}=0.18,75 \mathrm{p}=0.235)$. (Figure 13) 


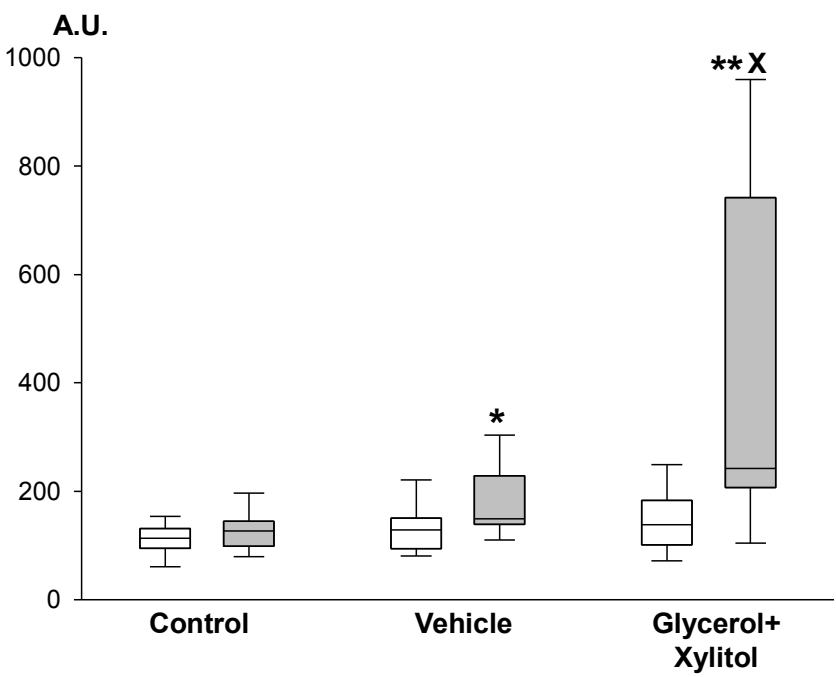

Figure 12. Friction values in non-treated, vehicle-treated and glycerol + xylitol-treated areas, respectively. White box plots demonstrate the values determined on day 0 (before treatment), while the grey box plots represent the values measured on day 14 (after the treatment period). Median values $(\mathrm{M})$ and the $25^{\text {th }}$ and $75^{\text {th }}$ percentiles are given. *: $\mathrm{p}<0.05$ vs day 0 values, **: $\mathrm{p}<0.001$ vs day 0 values, $\mathrm{X}: \mathrm{p}<0.05$ vs Control (nontreated).

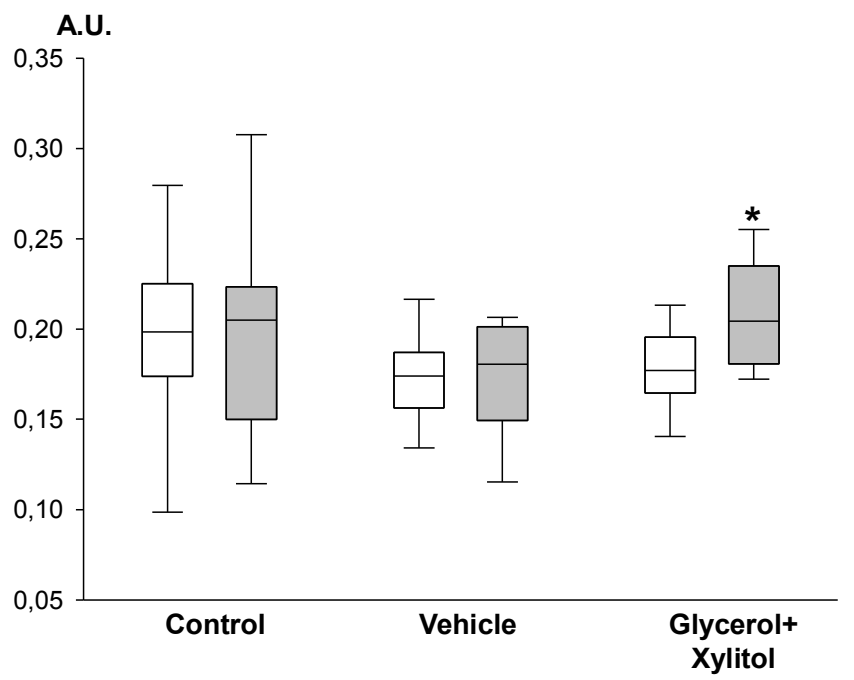

Figure 13. R0 values in the above mentioned areas. White box plots demonstrate the values determined on day 0 (before treatment), while the grey box plots represent the values measured on day 14 (after the treatment period). Median values $(\mathrm{M})$ and the $25^{\text {th }}$ and $75^{\text {th }}$ percentiles are given. $*$ : $<<0.05$ vs day 0 values. 


\subsubsection{EFFECTS OF POLYOLS ON MORPHOLOGICAL PARAMETERS}
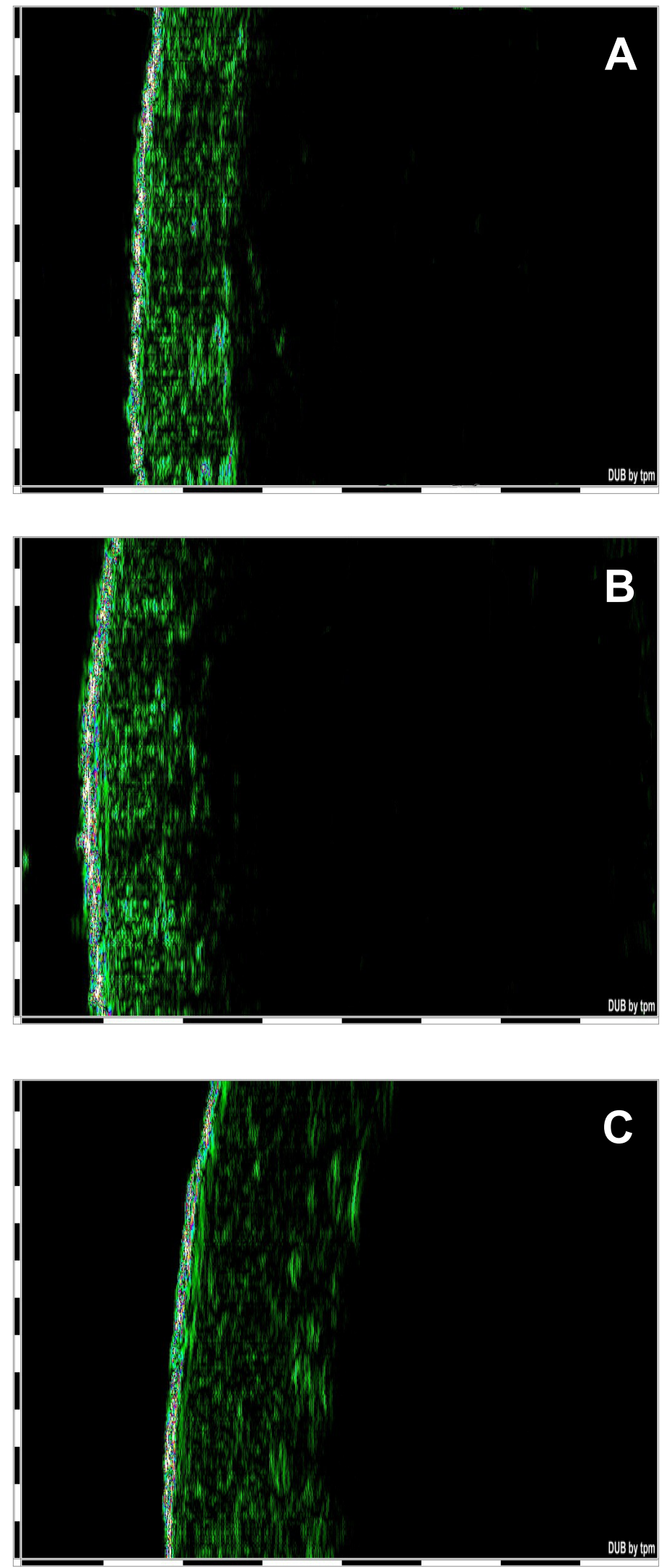

Figure 14. Images taken with the high-frequency, high-resolution ultrasound system. A: untreated (control) area, B: vehicle-treated area, C: glycerol + xylitol-treated area. Scale bar: $1 \mathrm{~mm}$. 
Figure 14 demonstrates images taken with the DUB ${ }^{\circledR}-U S B$ system. Figures 15-17 depicts the results obtained on the evaluation of the ultrasound images.

Exposure to glycerol and xylitol led to a significant increase in epidermal thickness (day 0: $M=187.67,25 p=175.33,75 p=218.33$, day $14: M=235.83,25 p=210.33,75 p=257.33)$. The vehicle alone did not induce changes in this parameter that differed statistically from the day 0 values (vehicle: day $0: M=212.33,25 p=192.92,75 p=223.92$, day $14: M=223.83,25 p=196.0$, $75 p=231.33)$. (Figure 15)

The dermal thickness was also enhanced by glycerol and xylitol. However, such changes were not found in the other areas (control: day 0: $\mathrm{M}=1564.0,25 \mathrm{p}=1317.17,75 \mathrm{p}=1846.67$, day 14 : $\mathrm{M}=1678.33, \quad 25 \mathrm{p}=1319.25, \quad 75 \mathrm{p}=1939.58$, vehicle: day $0: \mathrm{M}=1448.0, \quad 25 \mathrm{p}=1201.08$, $75 \mathrm{p}=1871.17$, day $14: \mathrm{M}=1586.17,25 \mathrm{p}=1248.75,75 \mathrm{p}=1836.08$, glycerol + xylitol: day 0 : $\mathrm{M}=1539.33,25 \mathrm{p}=1406.33,75 \mathrm{p}=1690.33$, day $14: \mathrm{M}=1776.17,25 \mathrm{p}=1538.33,75 \mathrm{p}=1942.75)$.

\section{(Figure 16)}

Both the vehicle and the preparation with glycerol and xylitol decreased the echogenicity of the papillary dermis. However, the polyols led to a more considerable reduction in this parameter and a difference was also found compared with the control area (control: day 0: $\mathrm{M}=14.0,25 \mathrm{p}=10.5,75 \mathrm{p}=20.25$, day $14: \mathrm{M}=14.0,25 \mathrm{p}=10.25,75 \mathrm{p}=18.88$, vehicle: day 0 : $\mathrm{M}=14.75,25 \mathrm{p}=13.25,75 \mathrm{p}=17.25$, day $14: \mathrm{M}=14.0,25 \mathrm{p}=11.25,75 \mathrm{p}=16.56$, glycerol + xylitol: day 0: $\mathrm{M}=14.0,25 \mathrm{p}=12.25,75 \mathrm{p}=15.38$, day $14: \mathrm{M}=10.0,25 \mathrm{p}=9.13,75 \mathrm{p}=11.13$ ). (Figure 17) As demonstrated by the histological images, the interdigitation index displayed relatively low values in the control area (control: $M=1.11,25 \mathrm{p}=1.06,75 \mathrm{p}=1.19$ ). 14 days of use of glycerol and xylitol resulted in a more expressed interdigitation between the epidermis and the dermis compared with the untreated control (glycerol + xylitol: $\mathrm{M}=1.26,25 \mathrm{p}=1.18,75 \mathrm{p}=1.32$ ). The vehicle did not appear to influence the interdigitation (vehicle: $M=1.11,25 \mathrm{p}=1.06,75 \mathrm{p}=1.18$ ).

\section{(Figure 18, Figure 19)}

In the control areas, approximately $25 \%$ of the epidermal cells showed positivity to filaggrin. Exposure to glycerol and xylitol increased this ratio considerably (control: $M=19.25$, $25 \mathrm{p}=15.13,75 \mathrm{p}=33.88$, glycerol + xylitol: $\mathrm{M}=37.9,25 \mathrm{p}=23.87,75 \mathrm{p}=47.53)$. Application of the vehicle was not accompanied by changes in the expression of filaggrin (vehicle: $M=24.5$, $25 \mathrm{p}=15.44,75 \mathrm{p}=31.0)$. (Figure 20, Figure 21)

MMP-1 protein was also found to be present in the epidermis. However, the applied formulations did not change the quantity of MMP-1. No significant difference was found between the control and the treated areas in terms of MMP-1 (data not shown). 


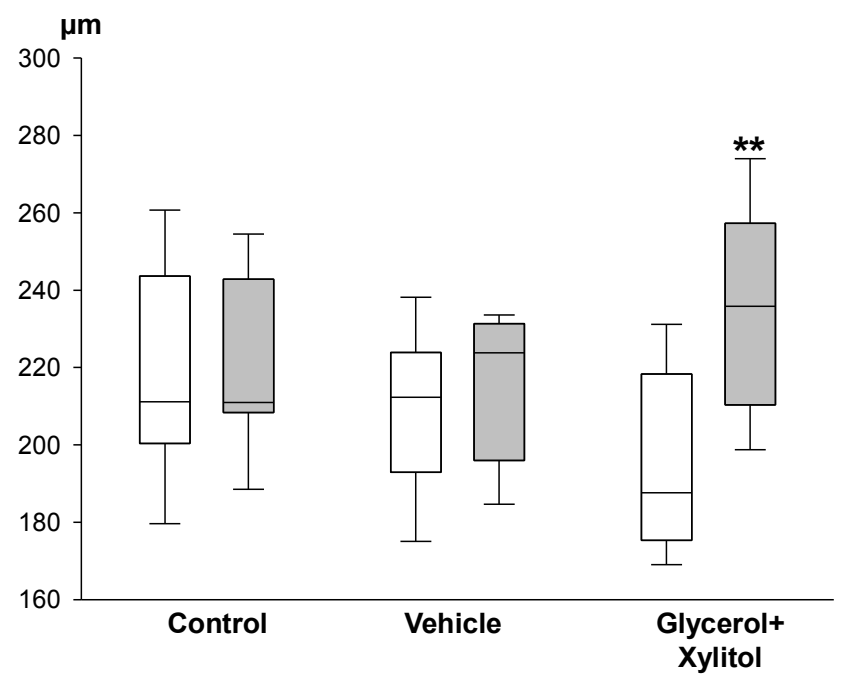

Figure 15. Effects of the applied preparations on epidermal thickness. White box plots demonstrate the values determined on day 0 (before treatment), while the grey box plots represent the values measured on day 14 (after the treatment period). Median values (M) and the $25^{\text {th }}$ and $75^{\text {th }}$ percentiles are given. ${ }^{*}: \mathrm{p}<0.001$ vs day 0 values.

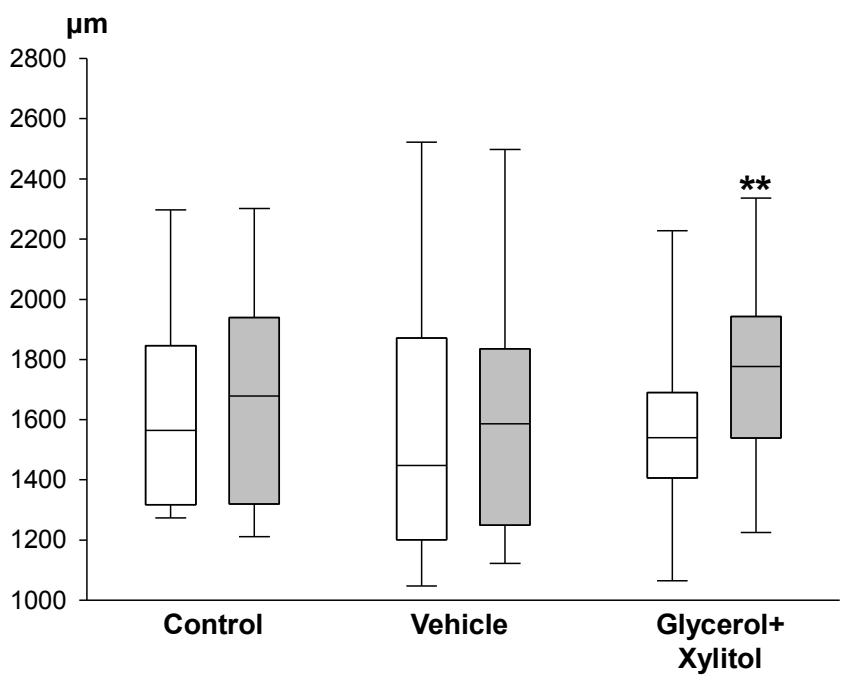

Figure 16. Changes in dermal thickness after 14 days of treatment. White box plots demonstrate the values determined on day 0 (before treatment), while the grey box plots represent the values measured on day 14 (after the treatment period). Median values $(\mathrm{M})$ and the $25^{\text {th }}$ and $75^{\text {th }}$ percentiles are given. $* *: p<0.001$ vs day 0 values. 


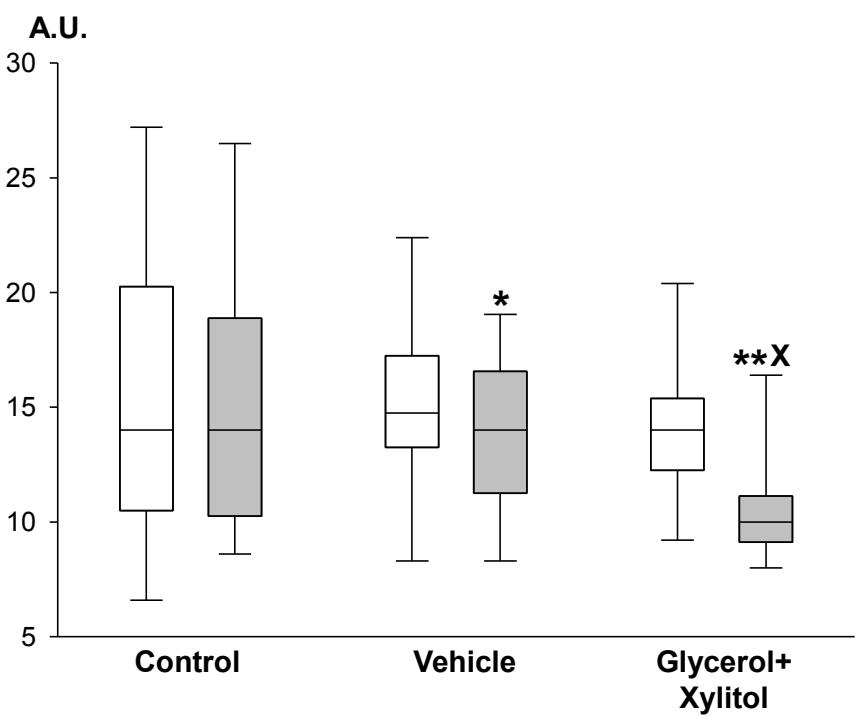

Figure 17. Alterations in the echogenicity of the papillary dermis in non-treated, vehicle-treated and glycerol + xylitol treated areas, respectively. White box plots demonstrate the values determined on day 0 (before treatment), while the grey box plots represent the values measured on day 14 (after the treatment period). Median values $(\mathrm{M})$ and the $25^{\text {th }}$ and $75^{\text {th }}$ percentiles are given. $*$ : $\mathrm{p}<0.05$ vs day 0 values, $* *: \mathrm{p}<0.001$ vs day 0 values, $\mathrm{X}: \mathrm{p}<0.05$ vs Control (non-treated). 

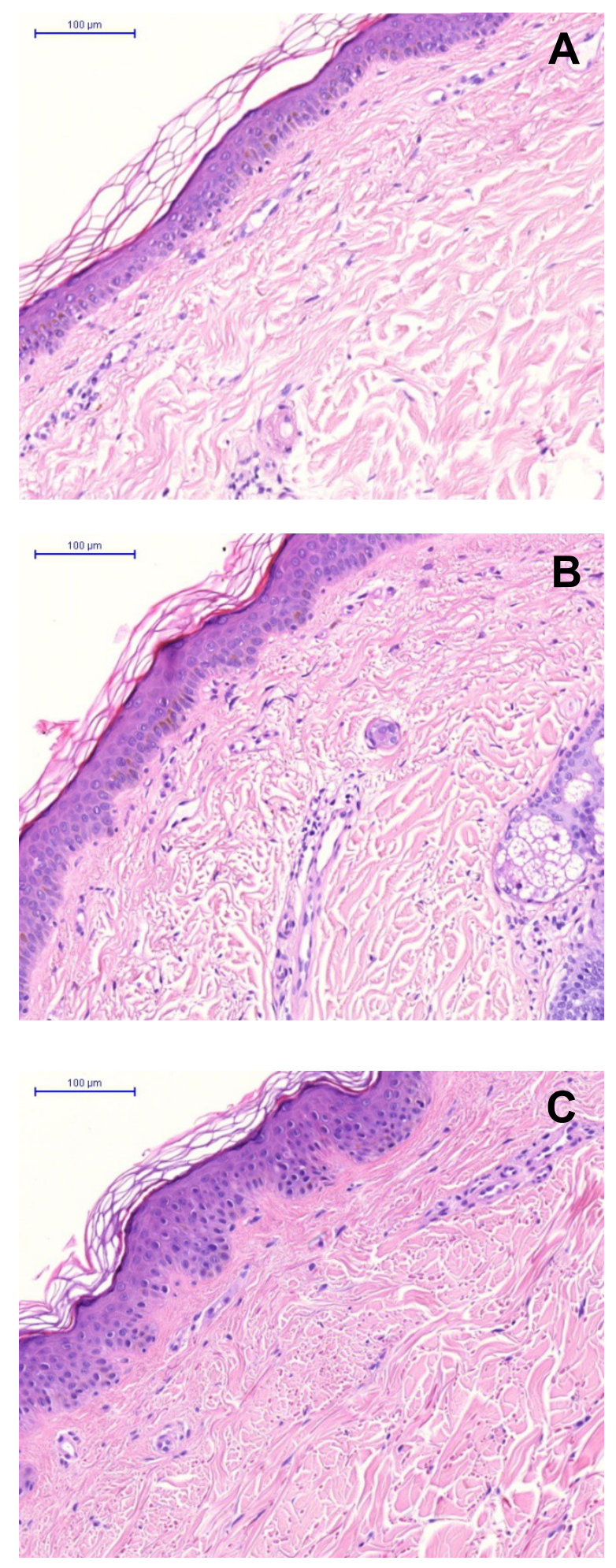

Figure 18. Photomicrographs of the skin from different areas (H\&E staining; scale bar $100 \mu \mathrm{m})$. A: Control, B: Vehicle-treated skin, C: Skin exposed to glycerol + xylitol. 


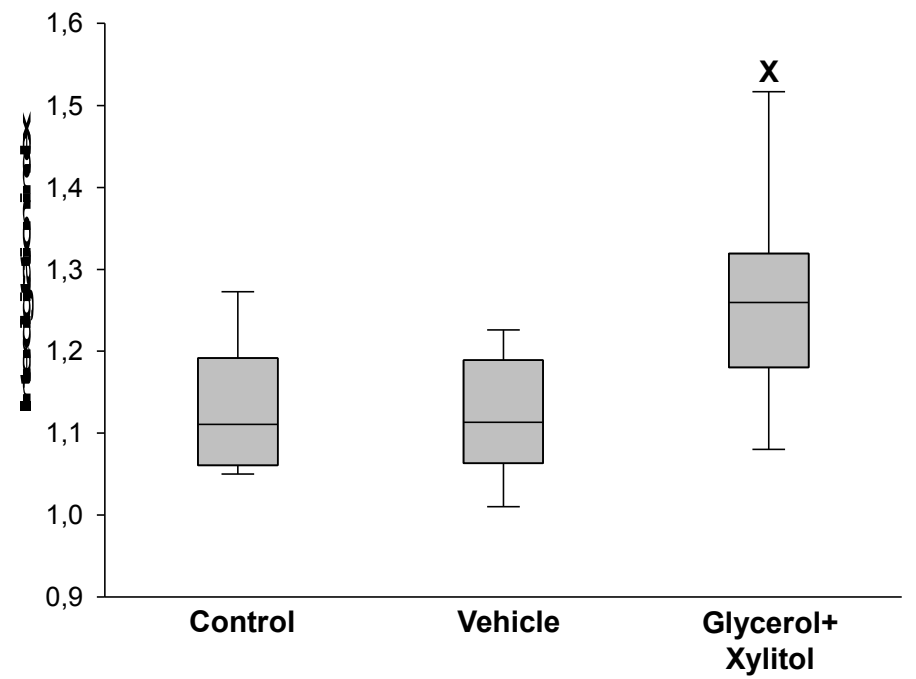

Figure 19. Interdigitation index of the non-treated, vehicle-treated and glycerol + xylitol treated areas, respectively. Median values $(\mathrm{M})$ and the $25^{\text {th }}$ and $75^{\text {th }}$ percentiles are given. $X: \mathrm{p}<0.05$ vs Control. 

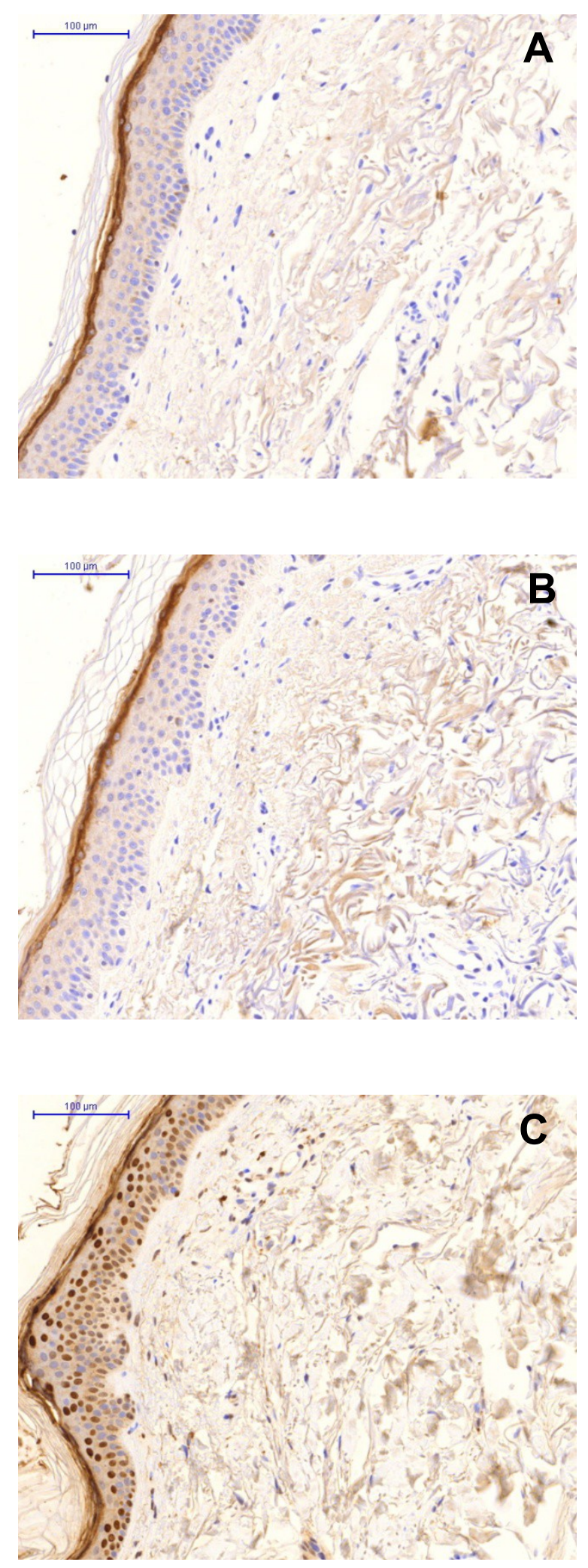

Figure 20. Presence of filaggrin in the epidermis (immunohistochemistry for filaggrin, counterstaining with haematoxylin; filaggrin positive cells appear brown; scale bar $100 \mu \mathrm{m})$. A: Control, B: Vehicle-treated skin, C: Skin exposed to glycerol + xylitol. 


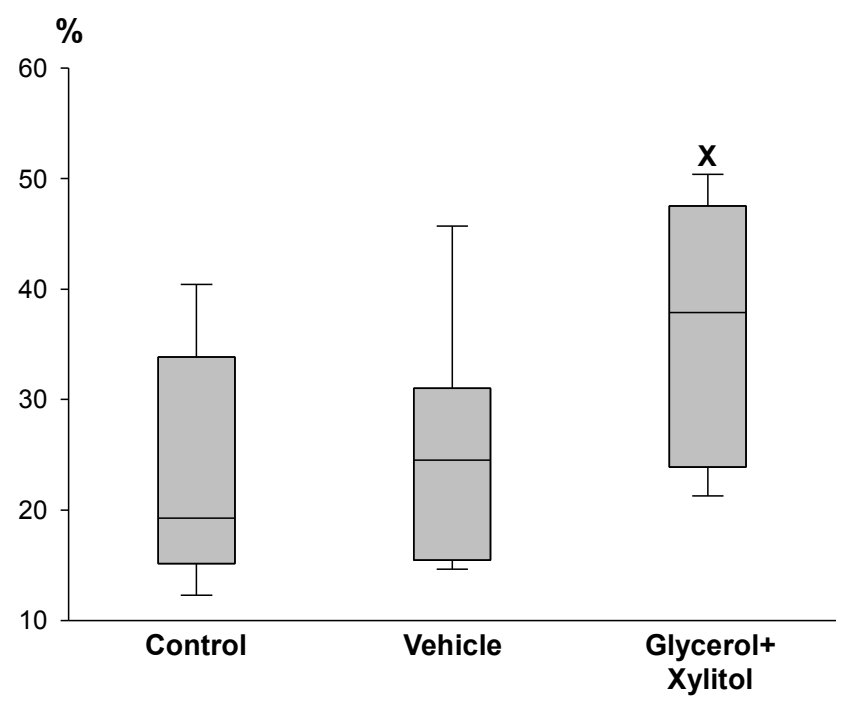

Figure 21. Ratio of the filaggrin-positive cells expressed as percentage. Median values $(\mathrm{M})$ and the $25^{\text {th }}$ and $75^{\text {th }}$ percentiles are given. $\mathrm{X}: \mathrm{p}<0.05$ vs Control.

Table 3 summarizes the effects of locally applied L-methionine on the studied parameters. According to the statistical analysis, no considerable change was found in any of these parameters after 14 days of treatment with L-methionine.

Table 3. Changes in the studied parameters after exposure to L-methionine.

\begin{tabular}{|c|l|l|l|l|l|l|}
\hline \multirow{2}{*}{ Parameter } & \multicolumn{3}{|c|}{ Day 0} & \multicolumn{3}{c|}{ Day 14} \\
\cline { 2 - 7 } & \multicolumn{1}{|c|}{$\mathrm{M}$} & \multicolumn{1}{|c|}{$25 \mathrm{p}$} & \multicolumn{1}{c|}{$75 \mathrm{p}$} & \multicolumn{1}{c|}{$\mathrm{M}$} & \multicolumn{1}{c|}{$25 \mathrm{p}$} & \multicolumn{1}{c|}{$75 \mathrm{p}$} \\
\hline Skin hydration & 20.0 & 16.48 & 25.03 & 25.17 & 17.29 & 31.66 \\
\hline TEWL & 9.75 & 7.5 & 12.0 & 8.05 & 6.98 & 10.58 \\
\hline Friction values & 107.7 & 76.75 & 144.3 & 112.8 & 93.65 & 123.35 \\
\hline R0 values & 0.182 & 0.17 & 0.21 & 0.17 & 0.157 & 0.2 \\
\hline Epidermal thickness & 185.0 & 179.75 & 207.75 & 212.17 & 185.25 & 221.33 \\
\hline Dermal thickness & 1648.17 & 1145.17 & 1940.17 & 1421.83 & 1139.42 & 1804.75 \\
\hline Echogenicity & 17.0 & 11.0 & 20.0 & 16.5 & 11.0 & 19.88 \\
\hline Interdigitation index & - & - & - & 1.17 & 1.1 & 1.23 \\
\hline Ratio of filaggrin positive cells & - & - & - & 25.85 & 16.38 & 36.5 \\
\hline
\end{tabular}

\section{DISCUSSION}


Antiirritants, as a group, include many different compounds that are added to topical products to reduce the irritative effects of other components (Andersen et al., 2006). An important goal of our study was to evaluate the effects of various polyols and amino acids on SLSinduced skin irritation. When planning the experimental setup, we considered that SLS is the most widely accepted irritant to evoke a mild inflammatory reaction in the skin by influencing the skin's barrier function. Abundant data on the application of SLS and the evaluation of skin irritation tests are found in the literature (Lee \& Maibach, 1995; Tupker et al., 1997; Agner et al., 2000; Tupker, 2005; Seidenari et al., 2005). The most likely explanation of the SLSinduced increase in TEWL is hyperhydration of the SC and possible disorganization of the lipid bilayers (Leveque et al., 1993). A statistically significant linear relationship has been observed between the dose of SLS and the resulting skin response (Agner \& Serup, 1990).

The combination of SLS with another agent to test antiirritant effects has also been described (Ghosh \& Blankschtein, 2007). The concentration of the SLS applied was determined in accordance with our previous pilot studies. A concentration of $0.1 \%$ was chosen because it is sufficient to increase TEWL significantly but does not result in inflammation serious enough to cause major inconvenience or pain for the subjects. Moreover, there is no significant chance of micelle formation with this concentration. We decided not to use visual scoring for assessment because of its subjective nature, and the relatively low concentration of SLS did not lead to visible changes in the skin in most cases. Thus, in the present study, the severity of irritation could be gauged more precisely by bioengineering methods. The determination of TEWL has been reported to be an appropriate and sensitive assessment of skin irritation. TEWL increases when barrier function is impaired; this elevation precedes visible clinical signs.

The concentration of the study agents was a further important consideration. According to the literature, glycerol at a concentration of approximately 10\% may have an antiirritant effect (Andersen et al., 2006). Although the efficacy of glycerol at a concentration of less than 5\% seemed to be dubious, we decided to examine this range as well because most researchers have used higher concentrations. The concentrations of the other agents were determined on the basis of glycerol concentrations. For better comparability, we designed solutions containing the same molar quantities of polyols and amino acids as the appropriate solutions of glycerol. Thus, $4.5 \%$ and $15 \%$ solutions of xylitol and $5.4 \%$ and $18 \%$ solutions of mannitol contained as much active agent as $2.6 \%$ and $9 \%$ solutions of glycerol, respectively. Concerning taurine, it was not possible to use a concentration higher than $8.4 \%$ because of the 
solubility of the material. Similarly, $5 \%$ was the highest concentration of glycine that could be used in the study.

Our data confirmed that glycerol effectively suppressed SLS-induced irritation of the skin when pre- and postpatch TEWL values and untreated and treated sites, respectively, were compared. Xylitol, mannitol and taurine also demonstrated antiirritant effects whereas glycine failed to do so.

Glycerol, which has effectively been used in topical formulations for decades, was found to exert an antiirritant effect in cases of experimentally induced contact dermatitis (Fluhr et al., 1999). However, glycerol is not only an antiirritant compound but also a potent moisturizer (although these categories show some overlap). Moisturizers of different types are cornerstones for the treatment of dry skin since they can promote barrier repair, reduce TEWL or contribute to aesthetic improvement of irritated skin (Draelos, 2013). Glycerol, together with other polyols, lactic acid, urea and amino acids, belongs to the humectants which is one of the three main classes of moisturizers (Kemény et al., 2016). Humectants hydrate the skin mainly by attracting and binding water from the deep dermis and environment. Compared to other formulations, they are absorbed faster and therefore are aesthetically better, promoting patient compliance (Lodén, 2006; Draelos, 2013). As described in the Introduction, several mechanisms contribute to the beneficial effects of glycerol (e.g. direct water binding ability, interaction with SC lipids and proteins, effects on average aqueous pore radius, etc.). In addition to these beneficial effects, glycerol is regarded completely safe.

We presumed that other compounds, possibly those of humectant group, may also positively affect skin barrier function. The cosmetologic applicability of urea is well-known and it has also been studied (Savica et al., 2004), but the polyols xylitol and mannitol have not been tested under in vivo conditions. Although in vitro data have been reported on their waterbinding properties, in vitro and in vivo effects may differ (Sagiv \& Marcus, 2003). According to our results, both mannitol and xylitol can reduce TEWL, i.e. provide protection against SLS-induced skin irritation. However, these polyols differently affect other skin physiological parameters. Mannitol hydrates the skin when it is injected together with hyaluronic acid (Taieb et al., 2012), while xylitol considerably increases hydration values alone when applied topically (Szél et al., 2015). Interestingly, further polyols, which were not involved in our studies, may be advantageous for the skin, as well, e.g. sorbitol was reported to exhibit significant improvement in both barrier and moisturization (Muizzuddin et al., 2013). 
Considering the beneficial properties of glycerol and xylitol and a possible synergistic effect, which may originate in their different effect of gene expression (Szabó-Papp et al., 2012), examination of their combined application seemed to be useful.

Study II has revealed that the glycerol- and xylitol-containing Xylinep ${ }^{\circledR}$ gel is able to decrease bacterial colonization both in vitro and in vivo. Furthermore, this preparation hydrates the skin for 24 hours. It is an important question, in which proportion the two polyols contribute to the mentioned effects. Glycerol in $85 \%$ concentration was found to have antibacterial effects, but Gram-positive species are less susceptible to glycerol than Gramnegatives (Saegman et al., 2007). On the other hand, 5\% xylitol can reduce the Streptococcus mutans counts even if the bacteria form a biofilm (Marttinen et al., 2012). Xylitol may inhibit bacterial proliferation by different mechanisms. Streptococcus mutans synthesizes xylitol-5-phosphate from xylitol, xylitol-5-phosphate is then dephosphorylated and this energy-consuming futile xylitol cycle inhibits bacterial growth (Trahan, 1995). Moreover, xylitol inhibits the formation of glycocalyx in $S$. aureus (Katsuyama et al., 2005b) and was found to have beneficial effects on both the oxidative killing of bacteria in neutrophilic leukocytes and on survival of rats with experimental pneumococcal sepsis (Renko et al., 2008). Thus, it can be concluded that xylitol is responsible for the antibacterial effect of the formulation. However, both polyols contribute to the hydration of the skin. According to recent results of our working group, both glycerol and xylitol provide protection against increase of TEWL and decrease of hydration in an animal model of ICD, and xylitol is also able to hamper penetration of SLS into the deeper layers of the skin (Szél et al., 2015). Due to these properties, a glycerol- and xylitol-containing formulation may contribute to the prevention of ICD. In terms of this disease, the antibacterial effect of the combined formulation shall also be underlined, because reduction of contamination in irritated skin is more difficult than that in healthy skin (de Almeida e Borges et al., 2007).

Nevertheless, Study II characterized the effects of polyols only in a relatively short period. Study III has shown that a longer application of glycerol and xylitol increases not only the water content of SC, but also that of the deeper layers. Ultrasound imaging has revealed an elevation in both epidermal and dermal thickness after exposure to the polyols. Thickening of the skin can be regarded as a marker of hydration (Mak et al., 2014). However, different skin diseases (e.g. inflammation) may also lead to swelling, but no sign of such disorders was detected in our study. Moreover, the echogenicity of the papillary dermis was measured to be lower and can be explained in terms of the binding of a larger amount of water due to the moisturizing effect (Mlosek et al., 2013). 
Improvement of the studied biomechanical parameters may also originate in the hydrating effect of glycerol and xylitol. Since the friction coefficient correlates positively with the hydration of the SC (Zhu et al., 2011), the higher friction values, i.e. the smoother skin, detected in our investigation may be explained in terms of a higher water content of the skin. The parameter R0, which reflects the passive behavior of the skin to force, was also found to be higher after the application of polyols. R0 demonstrates a positive correlation with hydration (Dobrev, 2000) and can be used as a marker in the study of hydrating agents (Wissing \& Müller, 2003). However, another study has suggested that the effects of glycerol on the mechanical parameters may be independent of its hydrating ability (Bettinger et al., 1999). Thus, the plasticity and distensibility of the skin may be influenced not only by hydration, but also by other mechanisms. The effects of glycerol on the epidermal lipid structure may explain its beneficial impact on its mechanical properties (Pedersen \& Jemec, 1999). Nevertheless, we have confirmed by means of different methods that glycerol and xylitol considerably increase the water content in the superficial and deeper layers of the skin. The water-binding capacity of the polyols, originating in their chemical structure is a possible, but not the only, explanation of the hydrating effect. An important new finding of our study is that the application of these polyols increases the quantity of filaggrin at the protein level in the skin. The preliminary in vitro data suggest that xylitol leads to an elevated protein expression of filaggrin (Szabó-Papp et al., 2012). Since the application of glycerol alone does not seem to influence the expression of filaggrin in vivo (Hoppe et al., 2015), it can be assumed that xylitol is responsible for the increased quantity of filaggrin. However, the exact mechanism via which this polyol elevates the expression of filaggrin demands further investigation. Although the vehicle alone (as an aqueous solution) influences few parameters, which may suggest some hydrating effect of this preparation, the application of the glyceroland xylitol-containing gel was accompanied by a more expressed hydration of the skin, the filaggrin expression was not altered by the vehicle. The polyols therefore seem to be responsible for the real hydrating ability of the preparation.

Besides hydration, glycerol and xylitol effectively improve barrier function of the skin, as indicated by reduced TEWL values. As Study II revealed, exposure to glycerol and xylitol for 24 hours increased SC hydration, which was not accompanied by a change in TEWL. Thus, a longer application of polyols appears to be needed for an improvement of the barrier function. This finding is in accordance with those of previous studies, which conclude that the use of glycerol for at least 3 days reduces TEWL significantly (Fluhr et al., 1999; Gloor \& Gehring, 2001). Xylitol tends to decrease TEWL in patients with AD after 7 days of use, but 
this change is not significant (Katsuyama et al., 2005a). The hydrating effect of the polyols may be a potential explanation for the improvement of TEWL. An inverse relationship between TEWL and SC hydration is well-known and moisturizers often improve barrier function. The mechanism of this interplay has not yet been fully clarified (Proksch et al., 2008). However, the filaggrin expression and NMF level appear to contribute to the skin barrier integrity. An age-related decline in barrier function has been described (Ghadially et al., 1995) and it may be connected with a lower NMF level in aged skin (Rawlings \& Harding, 2004). A recent study revealed that exposure to irritants, which results in barrier disruption, decreases the levels of NMF (Angelova-Fischer et al., 2014). Thus, influencing the NMF level via the filaggrin expression may contribute to the antiirritant effect of the polyols.

Histological analysis has revealed that the morphology of the dermal-epidermal junction (DEJ) is also influenced by the polyol treatment. It is known that skin ageing is accompanied by the flattering of the DEJ, and the rate of ridge height increase decreases with age (Giangreco et al., 2010). The interdigitation index is an appropriate indicator for the characterization of this alteration (Timár et al., 2000). Morphological changes of ageing may originate in dermal atrophy, decreased collagen biogenesis and loss of elastic fibers (Gilchrest, 1982; Varani et al., 2006). An elevation in interdigitation index after exposure to polyols might indicate some rejuvenation effect of glycerol and xylitol. Since ultrasound images have shown that polyol-induced hydration affects not only the epidermis, but also the dermis, these compounds may interfere with age-related dermal alterations. However, it should be mentioned that polyols influenced neither the gross elasticity (parameter R2 of the Cutometer) nor the net elasticity (parameter R5 of the Cutometer) in the present study. Hence, no considerable restoration of the elastic fibers is to be expected. Moreover, glycerol and xylitol do not seem to decrease the quantity of MMP-1, which might have contributed to their potential anti-aging effect. Thus, a rejuvenation effect of the polyols and its mechanism requires further examination. Accordingly, the combined application of glycerol and xylitol exerts several beneficial effects on the skin.

On the other hand, the advantageous impact of the studied amino acids was less expressed. Taurine did not significantly reduce TEWL after exposure to SLS. However, TEWL after application of taurine at $8.4 \%$ was lower than that after application of taurine at $3.4 \%$. Further, treatment with taurine at $8.4 \%$ decreased TEWL as compared to treatment with SLS alone. Glycine was not found to have antiirritant effect and methionine also failed to influence the studied parameters in Study III. 
In conclusion, our work has revealed the antiirritant effects of glycerol, xylitol, mannitol and taurine and underlined the advantages originating in the combination of glycerol and xylitol. The explanation of their efficacy is that they induce direct physical and/or chemical changes in the skin, influence expression of different genes (not only expression of filaggrin but also that of inflammatory cytokines is affected by polyols (Szél et al., 2015)) and have microbiological effects, too. These results may broaden the possibilities for antiirritant protection, lead to development of new cosmetic products, and contribute to the therapy of certain dermatologic diseases.

\section{SUMMARY AND NEW FINDINGS}

Our in vivo investigation and in vitro experiments were focused on the applicability of polyols and amino acids for the maintenance of homeostasis in the skin. We have demonstrated that many of these compounds are effective.

- In a model of subclinical irritation, it has been shown that, in addition to glycerol, xylitol, mannitol and - in a limited way - taurine possess antiirritant effect.

- Combination of glycerol and xylitol decreases the number of viable bacteria in $S$. pyogenes and $S$. aureus cultures.

- Application of this combination considerably reduces germ number in vivo.

- Glycerol and xylitol together increase skin hydration, their long-term application. improves epidermal barrier function and lead to better mechanical properties of the skin.

- The mentioned combination positively influences morphological parameters of the skin (rejuvenation effect).

- Glycerol and xylitol increase the protein quantity of filaggrin. This may be an explanation of many above mentioned beneficial effects.

Hence, these agents can be utilized in cosmetic industry in order to prevent irritation and the combination of glycerol and xylitol may be useful additional therapy for dry skin and may also soothe the age-associated changes in the skin. 


\section{ACKNOWLEDGMENTS}

Firstly, I wish to express my sincere gratitude to Professor Lajos Kemény for initiating my scientific career and for providing me with the opportunity to perform my scientific work at the Department of Dermatology and Allergology and for his valuable scientific guidance and help.

I am indebted to Professor Shabtay Dikstein for the continuous support of the studies and for the fruitful discussions.

I would like to express my special appreciation and thanks to my advisor Dr. Gábor Erös, I could not have imagined having a better advisor and mentor. His guidance helped me in all the time of research and writing of this thesis.

I am appreciative to Zoltán Behány for his excellent contribution to my work, and sharing his expertise on dermatophysiological measurements with me.

I thank Dr. Erika Varga and Dr. Edit Szél for helping in histological evaluations and Dr. Kornélia Szabó for her essential contribution to the microbiological examinations. Special thanks to the technical staff of the laboratories for their skillful assistance.

I thank Dr. Gábor Mohos for performing the skin biopsies and Dr. Ágnes Dura for preparing the tested formulations. 


\section{REFERENCES}

Agner T, Serup J. Skin reactions to irritants assessed by non-invasive bioengineering methods. Contact Dermatitis 1989; 20:352-359.

Agner T, Serup J. Sodium lauryl sulfate for irritant patch testing - a dose-response study using bioengineering methods for determination of skin irritation. J Invest Dermatol 1990; 95:543-547.

Anderheggen B, Jassoy C, Waldmann-Laue M, Förster T, Wadle A, Doering T. Taurine improves epidermal barrier properties stressed by surfactants - a role for osmolytes in barrier homeostasis. J Cosmet Sci 2006; 57: 1-10.

Andersen F, Hedegaard K, Petersen TK, Bindslev-Jensen C, Fullerton A, Andersen KE. Antiirritants I: doseresponse in acute irritation. Contact Dermatitis 2006; 55:148-154.

Andersen F, Hedegaard K, Petersen TK, Bindslev-Jensen C, Fullerton A, Andersen KE.. Comparison of the effect of glycerol and triamcinolone acetonide on cumulative skin irritation in a randomized trial. J Am Acad Dermatol 2007; 56:228- 235.

Angelova-Fischer I, Dapic I, Hoek AK, Jakasa I, Fischer TW, Zillikens D, Kezic S. Skin barrier integrity and natural moisturizing factor levels after cumulative dermal exposure to alkaline agents in atopic dermatitis. Acta Derm Venereol 2014; 94:640-644.

Appa Y, Orth DS, Widjaja J, Asuncion A: Effect of glycerin on energy requirements and liquid crystallinity of model intracellular lipids. J Invest Dermatol 1993; 100(4):587.

Atrux-Tallau N, Romagny C, Padois K, Denis A, Haftek M, Falson F, Pirot F, Maibach HI. Effects of glycerol on human skin damaged by acute sodium lauryl sulphate treatment. Arch Dermatol Res 2010; 302:435-441.

Beenken KE, Bradney L, Bellamy W, Skinner RA, McLaren SG, Gruenwald MJ, Spencer HJ, Smith JK, Haggard WO, Smeltzer MS. Use of xylitol to enhance the therapeutic efficacy of polymethylmethacrylate-based antibiotic therapy in treatment of chronic 
osteomyelitis. Antimicrob Agents Chemother 2012; 56:5839-5844.

Bettinger J, Gloor M, Vollert A, Kleesz P, Fluhr J, Gehring W. Comparison of different noninvasive test methods with respect to the effect of different moisturizers on skin. Skin Res Technol 1999; 5:21-27.

Cho JW, Jeong YS, Han J, Chun YJ, Kim HK, Kim MY, Kim BJ, Park KM, Kim JK, Kim JH, Cho SM. Skin hydration and collagen synthesis of AF-343 in HS68 cell line and NC/Nga mice by filaggrin expression and suppression of matrix metalloproteinase. Toxicol Res 2011; 27:225-229.

Cohen S, Marcus Y, Migron Y, Dikstein S., Shafran A.. Water sorption, binding and solubility of polyols. J Chem Soc Faraday Trans 1993; 89:3271-3275.

de Almeida e Borges LF, Silva BL, Gontijo Filho PP. Hand washing. Changes in the skin flora. Am J Infect Control. 2007; 35:417-20.

du Plessis J, Stefaniak A, Eloff F, John S, Agner T, Chou TC, Nixon R, Steiner M, Franken A, Kudla I, Holness L. International guidelines for the in vivo assessment of skin properties in non-clinical settings: Part 2. transepidermal water loss and skin hydration. Skin Res Technol 2013; 19:265-278.

Dobrev H. Use of Cutometer to assess epidermal hydration. Skin Res Technol 2000; 6:239244.

Draelos ZD. Moderns moisturizer myths, misconceptions and truths. Cutis 2013; 91:308-314.

Erős G, Kurgyis Z, Németh I, Csizmazia E, Berkó S, Szabó-Révész P, Kemény L, Csányi E: The irritant effects of pharmaceutically applied surfactants. J Surfact Deterg 2014; 17:67-70.

Fluhr JW, Gloor M, Lehmann L, Lazzerini S, Distante F, Berardesca E. Glycerol accelerates recovery of barrier function in vivo. Acta Derm Venereol 1999; 79:418-421. 
Fluhr JW, Darlenski R, Surber C. Glycerol and the skin: a holistic approach to its origin and functions. Br J Dermatol 2008; 159:23-34.

Froebe CL: Prevention of stratum corneum lipid phase transition in vitro by glycerol - an alternative mechanism for skin moisturization. J Soc Cosmet Chem 1990; 41:51-65.

Ghadially R, Brown BE, Sequeira-Martin SM, Feingold KR, Elias PM. The aged epidermal permeability barrier. Structural, functional and lipid biochemical abnormalities in humans and a senescent murine model. J Clin Invest 1995; 95:2281-2290.

Ghosh S, Blankschtein D. The role of sodium dodecyl sulfate (SDS) micelles in inducing skin barrier perturbation in the presence of glycerol. J Cosmet Sci 2007; 58:109-133.

Giangreco A, Goldie SJ, Failla V, Saintigny G, Watt FM. Human skin aging is associated with reduced expression of stem cell markers $\beta 1$ integrin and MCSP. J Invest Dermatol 2010; 130:604-608.

Gilchrest BA. Age-associated changes in the skin. J Am Geriatr Soc 1982; 30:139-143.

Gloor M, Gehring W. Increase in hydration and protective function of horny layer by glycerol and a W/O emulsion: are these effects maintained during long-term use? Contact Dermatitis 2001; 44:123-125.

Gloor M. How do dermatologic vehicles influence the horny layer? Skin Pharmacol Physiol 2004; 17:267-73.

Grafe F, Wohlrab W, Neubert RH, Brandsch M. Functional characterization of sodium- and chloride-dependent taurine transport in human keratinocytes. Eur J Pharm Biopharm 2004; 57:337-341.

Harding CR, Scott IR. Stratum corneum moisturizing factors. In: Skin Moisturization pp. 6180., eds.: JJ Leyden and AV Rawlings, Marcel Dekker, New York, 2002.

Harding CR, Aho S, Bosko CA: Filaggrin - revisited. Int J Cosmet Sci 2013; 35:412-423. 
Hoppe T, Winge MCG, Bradley M, Nordenskjöld M, Vahlquist A, Törmä H, Berne B.

Moisturizing treatment of patients with atopic dermatitis and ichthyosis vulgaris improves dry skin, but has a modest effect on gene expression regardless of FLG genotype. JEADV 2015; 29:174-177.

Imhof RE, De Jesus ME, Xiao P, Ciortea LI, Berg EP. Closed-chamber transepidemal water loss measurement: microclimate, calibration and performance. Int J Cosmet Sci 2009; 31:97118.

Katsuyama M, Kobayashi Y, Ichikawa H, Mizuno A, Miyachi Y, Matsunaga K, Kawashima M. A novel method to control the balance of skin microflora Part 2. A study to assess the effect of a cream containing farnesol and xylitol on atopic dry skin. J Dermatol Sci $2005 ; 38: 207-213$. (a)

Katsuyama M, Ichikawa H, Ogawa S, Ikezawa Z. A novel method to control the balance of skin microflora. Part 1. Attack on biofilm of Staphylococcus aureus without antibiotics. J Dermatol Sci. 2005; 38:197-205. (b)

Kemény L, Nagy N, Csoma Z, Szabó K, Erős G. Pharmacological Targeting of the Epidermal Barrier. Curr Pharm Des. 2016; DOI: 10.2174/1381612822666160726094947.

Lee $\mathrm{CH}$, Maibach HI. The sodium lauryl sulfate model: an overview. Contact Dermatitis $1995 ; 33: 1-7$.

Lee E, An S, Im MS, Kim HK, Lee TR. An improved method for measurement of change in skin roughness caused by cleansing products under mild application conditions. Skin Res Technol 2011; 17:320-325.

Leite e Silva RV, Schulman MA, Ferelli C, Gimenis JM, Ruas GW, Baby AR, Velasco MV, Taqueda ME, Kaneko TM. Hydrating effects of moisturizer active compound incorporated into hydrogels: in vivo assessement and comparison between devices. J Cosmet Dermatol 2009; 8:32-39. 
Leveque JL, de Rigal J, Saint-Leger D, Billy D. How does sodium lauryl sulfate alter the skin barrier function in man? A multiparametric approach. Skin Pharmacol 1993; 6:111-115.

Loesche WJ, Grossman NS, Earnest R,, Corpron R.. The effects of chewing xylitol gum on the plaque and saliva levels of Streptococcus mutans. J Am Dent Assoc 1984; 108:587-592.

Lodén M. The clinical benefit of moisturizers. J Eur Acad Dermatol Venereol. 2005; 19:672688.

Ly KA, Milgrom P, Rothen M. Xylitol, sweeteners, and dental caries. Pediatr Dent 2006; 28:154-163.

Mak TM, Huang YP, Wang LK, Zheng YP. Ultrasound biomicroscopy measurement of skin thickness change induced by cosmetic treatment with ultrasound stimulation. Ultrasonics 2014; 54: 1395-1400.

Marrubini G, Caccialanza G, Massolini G. Determination of glycine and threonine in topical dermatological preparations. J Pharm Biomed Anal 2008; 47:716-722.

Marttinen AM, Ruas-Madiedo P, Hidalgo-Cantabrana C, Saari MA, Ihalin RA, Söderling EM. Effect of xylitol on xylitol- sensitive versus xylitol-resistant Streptococcus mutans strains in a three-species in vitro biofilm. Curr Microbiol 2012; 65:237-243.

Mattila P, Svanberg M, Knuuttila M. Diminished bone resorption in rats after oral xylitol administration: a dose-response study. Calcif Tissue Int 1995; 56:232-235.

Mlosek RK, Malinowska S, Sikora M, Debowska R, Stepien A, Czekaj K, Dabrowska A. The use of high frequency ultrasound imaging in skin moisturization measurement. Skin Res Technol 2013; 19:169-175.

Muizzuddin N, Ingrassia M, Marenus KD, Maes DH, Mammone T. Effect of seasonal and geographical differences on skin and effect of treatment with an osmoprotectant: Sorbitol. J Cosmet Sci 2013; 64:165-174. 
Pedersen LK, Jemec GBE. Plasticising effect of water and glycerin on human skin in vivo. J Dermatol Sci 1999; 19:48-52.

Proksch E, Fölster-Holst R, Jensen JM. Skin barrier function, epidermal proliferation and differentiation in eczema. J Dermatol Sci 2006; 43:159-169.

Proksch E, Brandner JM, Jensen JM. The skin: an indispensable barrier. Exp Dermatol 2008; 17:1063-1072.

Quan T, Qin Z, Xia W, Shao Y, Voorhees JJ, Fisher GJ. Matrix-degrading metalloproteinases in photoaging. J Investig Dermatol Symp Proc 2009; 14:20-24.

Rawlings AV, Harding CR: Moisturization and skin barrier function. Dermatol Ther 2004; 17 (Suppl 1):43-48.

Renko M, Valkonen P, Tapiainen T, Kontiokari T, Mattila P, Knuuttila M, Svanberg M, Leinonen M, Karttunen R, Uhari M. Xylitol-supplemented nutrition enhances bacterial killing and prolongs survival of rats in experimental pneumococcal sepsis. BMC Microbiol 2008; $8: 45$.

Rockel N, Esser C, Grether-Beck S, Warskulat U, Flögel U, Schwarz A, Schwarz T, Yarosh D, Häussinger D, Krutmann J. The osmolyte taurine protects against ultraviolet B radiationinduced immunosuppression. J Immunol 2007; 179:3604-3612.

Rogiers V. EEMCO guidance for the assessment of transepidermal water loss in cosmetic sciences. Skin Pharmacol Appl Skin Physiol 2001; 14:117-128.

Saegman VS, De Vos R, Tebaldi ND, van der Wolf JM, Bergervoet JH, Verhaegen J, Lismont D, Verduyckt B, Ectors NL. Flow cytometric viability assessment and transmission electron microscopic morphological study of bacteria in glycerol. Microsc Microanal 2007; 13:18-29.

Sagiv AE, Marcus Y. The connection between in vitro water uptake and in vivo skin moisturization. Skin Res Technol 2003; 9:306-311. 
Savica S, Tamburic S, Savic M, Cekic N, Milic J, Vuleta G. Vehicle-controlled effect of urea on normal and SLS-irritated skin. Int J Pharm 2004; 271:269- 80.

Schwensen JF, Friis UF, Menné T, Johansen JD. One thousand cases of severe occupational contact dermatitis. Contact Dermatitis 2013; 68:259-268.

Seidenari S, Giusti F, Pellacani G. Instrumental evaluation of occluded patch test reaction. In: Serup J, Jemec GBE, Grove GL, editors. Handbook of non-invasive methods and the skin. Boca Raton: CRC Press; 2005. p. 973-9.

Sparavigna A, Tenconi B, De Ponti I. Antiaging, photoprotective and brightening activity in biorevitalization: a new solution for aging skin. Clin Cosmet Investig Dermatol 2015; 8:5765 .

Szabó-Papp J, Sós K, Oláh A, Szöllösi AG, Tóth BI, Czifra G, Bíró T. Differential effects of common moisturizer polyols on normal human epidermal keratinocytes. J Invest Dermatol 2012; 132:S58.

Szél E, Polyánka H, Szabó K, Hartmann P, Degovics D, Balázs B, Németh IB, Korponyai C, Csányi E, Kaszaki J, Dikstein S, Nagy K, Kemény L, Erős G. Anti-irritant and antiinflammatory effects of glycerol and xylitol in sodium lauryl sulphate-induced acute irritation. JEADV 2015; 29:2333-2341.

Taieb M, Gay C, Sebban S, Secnazi P. Hyaluronic acid plus mannitol treatment for improved skin hydration and elasticity. J Cosmet Dermatol. 2012; 11:87-92.

Tan CH, Rasool S, Johnston GA. Contact dermatitis: allergic and irritant. Clin Dermatol $2014 ; 32: 116-124$. 
Timár F, Soós G, Szende B, Horváth A. Interdigitation index - a parameter for differentiating between young and older skin specimens. Skin Res Technol. 2000; 6:17-20.

Thune P, Nilsen T, Hanstad IK, Gustavsen T, Lövig Dahl H. The water barrier function of the skin in relation to the water content of stratum corneum, $\mathrm{pH}$ and skin lipids. Acta Derm Venereol 1988; 68:277-283.

Trahan L. Xylitol: a review of its action on mutans streptococci and dental plaque - its clinical significance. Int Dent J 1995; 45(1 Suppl 1):77-92.

Tupker RA, Willis C, Berardesca E, Lee CH, Fartasch M, Agner T, Serup J. Guidelines on sodium lauryl sulfate (SLS) exposure tests. A report from the Standardization Group of the European Society of Contact Dermatitis. Contact Dermatitis 1997; 37:53-69.

Tupker RA. Testing ESCD application and reading standards. In: Serup J, Jemec GBE, Grove GL, editors. Handbook of non-invasive methods and the skin. Boca Raton: CRC Press; 2005. p. $943-55$.

Varani J, Dame MK, Rittie L, Fligiel SEG, Kang S, Fisher GJ, Voorhees JJ. Decreased collagen production in chronologically aged skin: roles of age-dependent alteration in fibroblast function and defective mechanical stimulation. Am J Pathol 2006; 168:1861-1868.

Warskulat U, Reinen A, Grether-Beck S, Krutmann J, Häussinger D. The osmolyte strategy of normal human keratinocytes in maintaining cell homeostasis. J Invest Dermatol 2004; 123:516-521.

Wissing SA, Müller RH. The influence of solid lipid nanoparticles on skin hydration and viscoelasticity - in vivo study. Eur J Pharm Biopharm 2003; 56:67-72.

Wu PF, Long LH, Zeng JH, Guan XL, Zhou J, Jin Y, Ni L, Wang F, Chen JG, Xie N. Protection of L-methionine against $\mathrm{H}_{2} \mathrm{O}_{2}$-induced oxidative damage in mitochondria. Food Chem Toxicol 2012; 50:2729-2735. 
Zaman RT, Parthasarathy AB, Vargas G, Chen B, Dunn AK, Rylander HG, Welch AJ. Perfusion in hamster skin treated with glycerol. Lasers Surg Med 2009; 41:492-503.

Zhu YH, Song SP, Luo W, Elias PM, Man MQ. Characterization of skin friction coefficient, and relationship to stratum corneum hydration in a normal Chinese population. Skin Pharmacol Physiol 2011; 24:81-86. 
APPENDIX 